\title{
Melodinen variointi porosaamelaisen Kaapin-Jounin joiussa
}

\section{Kaapin-Jouni ja porosaamelainen joikuperinne}

\subsection{Kaapin-Jouni, poromies ja joikumestari}

Kaapin-Jouni eli Jouni Gabrielinpoika Aikio (1875-1956) syntyi Utsjoella porosaamelaiseen ${ }^{1}$ perheeseen. Inarin alueen saamelaiset olivat toimineet enimmäkseen kalastajina sekä peuran ja majavan metsästäjinä, mutta riistakantojen pienennyttyä 1800-luvun aikana monet siirtyivät Aikioiden lailla laajamuotoiseen porotalouteen².

Kaapin-Jounin isä Annas-Kaapi (1834-1903) olikin lähtenyt 1800-luvun puolessa välissä Utsjoelle opettelemaan poroelinkeinoa. Annas-Kaapi meni naimisiin vuonna 1867 utsjokelaisen Ella Vuolabin (1844-1923) kanssa. Myötäjäisinä saadut porot muodostivat alun Annas-Kaapin omalle tokalle. Täysoppineena poromiehenä Annas-Kaapi palasi perheineen Inariin vuonna 1890. ${ }^{3}$

Perheen vanhimmasta pojasta Kaapin-Jounista kasvoi yksi Inarin 1900-luvun alun varakkaimmista poromiehistä. Poronelinkeinossa elävien tapaan KaapinJounikin joutui liikkumaan laajalti. Paulaharjun mukaan Jouni hallitsi Länsi-Inarissa 500-600:n tokkaa liikkuen milloin Maarestatunturissa, milloin Hammas- ja Viipastuntureissa sekä asuen väliin Lemmenjoella, väliin Ivalo-Matissa.

1900-luvun alussa Kaapin-Jounin kesäpaikaksi oli vakiintunut Hammasjärvi. Sieltä hänet löysi myös musiikintutkija Armas Launis, joka kierteli joikukeräysmatkoilla Lapissa kesinä 1904 ja 1905. Tuolloin vasta 30-vuotias Jouni osoittautui parhaimmaksi joikujen tuntijaksi, johon Launis matkoillaan törmäsi. Launis tallensi Kaapin-Jounilta 208 joikumelodiaa, joka muodostaa $29 \%$ hänen vuonna 1908 julkaisemansa joikukokoelman "Lappische Juoigos-Melodien" (Launis 1908) materiaalista.

Launis kertoi pienikokoisen "Joonin" äänen olleen "ko'on mukainen, kimakka tenori", mutta kerran alkuun päästyä oli ollut täysi työ kirjoittaa muistiin Jounin koko sävelmävarastoa. Hän osasi sävelmiä aina Tromssasta ja Polmankista saakka. Noin 20 vuotta myöhemmin Samuli Paulaharju tapasi tuolloin jo 50-vuotiaan 
Kaapin-Jounin. Paulaharjun kuvauksessa huomiota herättää Kaapin-Jounin ääni. Entinen kimakka tenori on saanut jopa paholaismaisia piirteitä (Launis 1922, 74-84; 109-144; Paulaharju 1927, 120-121):

"... Punaisissa lakeissa ja fietter-housuissa mies aina liikkuu, vakuutellen, ettei hänellä kyllä koskaan housunmalli muutu, vaikka muut kuinkakin uudenmallisia laittaisivat. Vaikka tämä Kaapin-Jounin toinen panos on lappalaiseksikin jäänyt aivan pikkuruiseksi tunturitontuksi, vain 'kinthankokoiseksi', on hänessä kyllä sekä miehen mieli että varsinkin ääni. Jos Jouni osaa hyvin käsitellä suurta tunturieloaan, niin vielä paremmin hän taitaa käsitellä isoa kurkkuansa. Jouni onkin ankara joikaamaan. Kun pikku mies tunturilla puhaltaa kurkustansa joikauksen, on koko kehveli äänenä, niin että sananpuhuvainen Kitti-Uulakin neljänneksien päässä sen kuulee ja kauhistuu. Mutta toiset tunturimiehet joikaavat pikku toveriaan:

'Naa Kaapin-Jouni,

niin niin niin,

pikku poika san naa lei,

lullu lullu lugu luu'."

Kaapin-Jounin joikaamista ei tiettävästi ole nauhoitettu vaikka hän eli 81-vuotiaaksi asti. Jounin pororikkaudetkin olivat hävinneet jo ennen sotia. Erkki Ala-Könni äänitti kuitenkin vuosina 1961 ja 1963 kaksi Kaapin-Jounin lesken Margareetan ja yksitoista pojan Uulan joikuesitystä. ${ }^{4}$

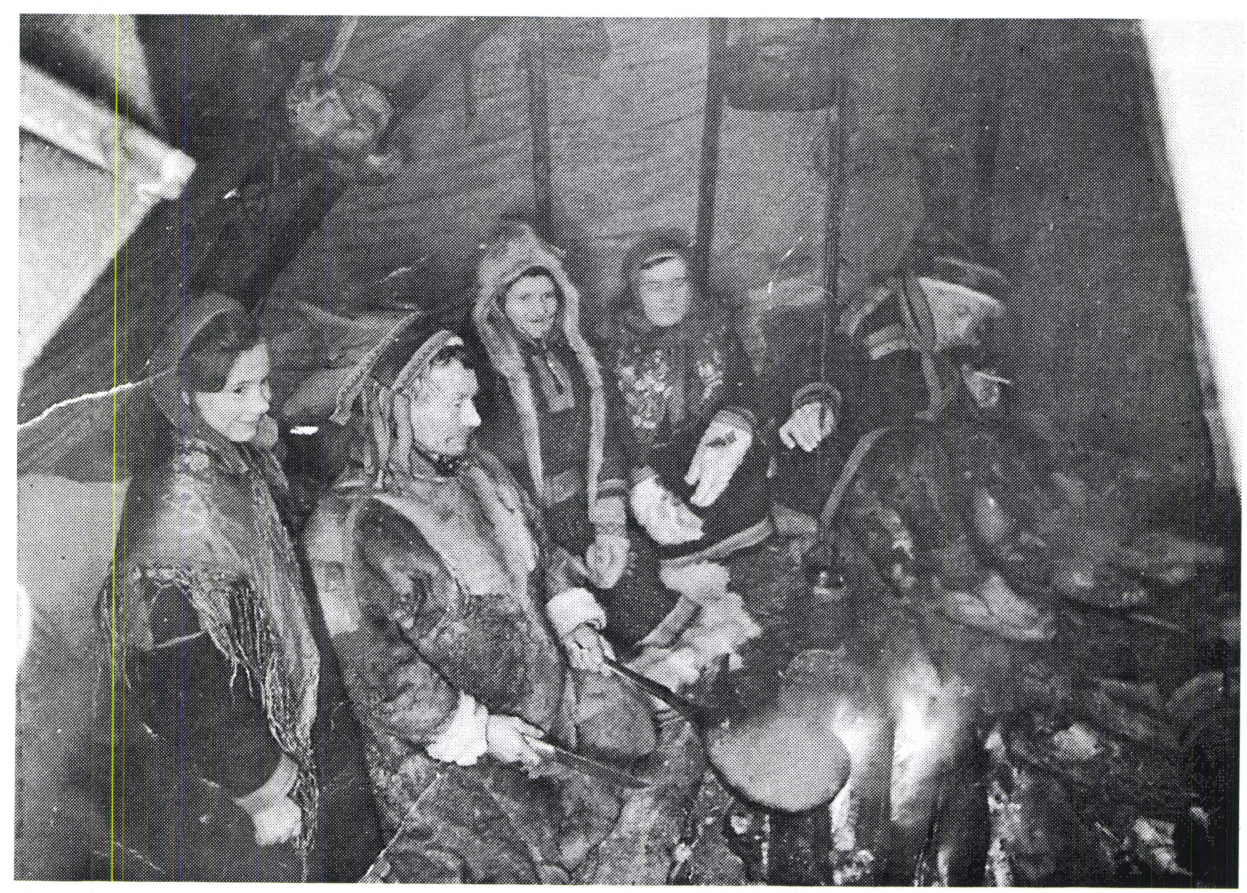

Kuva 1. Jouni Aikio eli Kaapin-Jouni toisena vasemmalta tekemässä käristystä 1930-luvulla. Kolmas vasemmalta on Jounin vaimo Margareeta. Lähde: Aune Huhtamellan paperit. 


\subsection{Joiku osana porosaamelaista kulttuuria}

Joikaaminen on porosaamelaisten vahvan tarinaperinteen ohella keino määrittää ja säilyttää muistissa ympäröivää maailmaa - niin ihmisiä, luonnonpaikkoja kuin sosiaalisia verkostojakin. Joiussa ei kerrota tarinaa tai kuvata tunteita länsimaisen laulun tapaan vaan pyritään kuvaamaan joiun kohde kokonaisvaltaisesti. Tämä kokonaisvaltaisuus sisältää ajatuksen siitä, että kohde omistaa joiun ja on yhtä joiun kanssa.

Joikatessaan henkilö ikään kuin kutsuu omasta tai yhteisön kollektiivisesta muistista joikattavan esille. Samalla joikaaja kuitenkin suhteuttaa itsensä kohteeseen ja näin joiku muodostaakin saamelaisille erittäin tärkeän kommunikaation välineen. Juuri tämän joiun kommunikatiivisen puolen takia jokainen yksittäinen joikuesitys on myös ainutkertainen kuvaus joikaajan suhteesta ja tuntemuksista joikattavaan.

Joiun teksti ei useimmiten sisällä paljoa kohdetta määrittäviä sanoja. Usein mainitaan pelkästään kohteen nimi ja muutama kohdetta kuvaava epigrammaattinen lause. Launis $(1986,19-23)$ muotoilee asian seuraavasti:

\footnotetext{
"Sanat ovatkin joikauksessa vaan sivuasia. Suurimman huomion panee lappalainen nuotille. Sen pitää - heidän makunsa mukaan - olla kaunis ja niin hyvästi kuin suinkin kuvata sitä henkilöä tai eläintä, josta on kysymys[...]"
}

Launis myös vakuuttui joiun kuvaavuudesta:

"[...]kun usein laulajat alkoivat kehuskella nuotin niin selvästi kuvaavan, minkälainen se ihminen on."

Suurimmaksi osaksi joikutekstit koostuvat lyhyistä pikkusanoista, jotka voidaan jakaa kolmeen ryhmään niiden funktion mukaan. 1) Ensimmäiseen ryhmään kuuluu kielellisen merkityksen omaavia konjunktioita kuten go (saam. kun, jolloin, koska), partikkeleita kuten de (saam. niin, siten, nyt, no nyt), juo (saam. jo, kerran, nyt, kyllä, niin, no niin), vel, velá(i) (saam. vielä) ja na (saam. no, niin) sekä olla-verbin muotoja kuten lea (hän on), ledjen (olin), lei (hän oli.). 2) Toisen ryhmän muodostavat metrin täydentämiseksi käytetyt sanat, jotka muuten kuuluisivat ensimmäiseen ryhmään, mutta esiintyessään varsinaisien tekstivirkkeiden ulkopuolella ne erottuvat lauseen ajatuksen yhteydestä. 3) Kolmanteen ryhmään kuuluvat tavut, joita ei käytetä tavallisessa puhekielessä vaan pelkästään joiuissa. Tavallisimmat ovat non-non, nun-nun, lol-lol, lul-lul, tai vouv-vov. Tätä ryhmää voi kutsua ilman sanoja laulamiseksi. Suomen kielellä laulettaessa lallatellaan esimerkiksi laa-laa-tavuilla. Joikujen yhteydessä tätä ilmiötä voisi kutsua vaikkapa nonnotteluksi tai lullutteluksi.

Viitteellisellä tekstillä, pikkusanoilla, nun-nun-tavuilla ja haluamillaan äänensävyillä joikaaja tuottaa kuuntelijoille assosiaatioita joiun kohteesta ja omasta suhteestaan kohteeseen (vrt. Laitinen 1981, 182-183). Joiun kohdetta määrittävän 
sanallisen informaation niukkuudesta johtuen inhimillisten tunteiden ilmaiseminen musiikillisin keinoin nousee joiuissa hyvin tärkeään asemaan.

Perinteiseen joikaamistilanteeseen kuuluu myös se, että joikaaja ja muut tilanteeseen osallistujat tuntevat kohteen, sen historian ja kohteeseen liittyvät tarinat jo entuudestaan. Näin heillä on mahdollisuus yhdistää joiun ei-sanallinen informaatio kohteeseen. Ilpo Saastamoisen $(1998,463)$ mukaan

"[j]oiku ei ole, vaan se sytyttää - mutta vain jos kuulijan mielessä on ennestään jotain, mikä voi syttyä".

Ymmärtämiseen tarvitaan siis koko kulttuurisen kontekstin ja kohteen henkilöhistorian tuntemista. Tutkimuksen kannalta on kuitenkin ongelmallista, että juuri joiun keskeinen, kommunikatiivinen puoli pakenee usein tarkkoja merkitysten määrityksiä.

Kun valtaosa aiemmasta tutkimuksesta on koettanut vastata kysymykseen "mitä joiku on", tämän artikkelin lähtökohtana on ennemminkin muusikon näkökulma, jossa kysyn "miten joikataan". Tarkoituksenani on ensinnäkin etsiä hyvinkin erilaisten toisintojen keskeltä Kaapin-Jounia merkitsevää musiikillista motiivia, joka tunnistetaan Kaapin-Jounin joiun perusosaksi ja joka on myös yhteinen perusta eri esittäjien Kaapin-Jounin joikauksille.

Toiseksi selvitän sitä, millä tavoin joiun musiikillisia elementtejä varioidaan ja minkälaiset piirteet tekevät kustakin joikuesityksestä persoonallisen. Huomioitavana ovat seuraavat elementit: 1) teksti, 2) melodia, 3) metri, 4) sävelasteiden toteuttaminen, 5) muoto ja 6) hengitys ${ }^{5}$. Keskityn ensisijaisesti varioinnin yksilöllisiin keinoihin, vaikka eri alueiden tyylilliset erot varmasti vaikuttavat esityksiin. On tosin ongelmallista, että alueellisia tyylieroja käsittelevää kattavaa tutkimusta ei ole toistaiseksi saatavilla6.

\section{Kaapin-Jounin joiun toisinnot Armas Launiksen kokoelmassa}

\subsection{Aslak Jomppasen esitys Kaapin-Jounin joiusta}

Vanhimmat tunnetut toisinnot Kaapin-Jounin joiusta löytyvät Launiksen kokoelmasta. Joiun n:o 653a joikasi kesällä 1904 Inarin Menesjärvellä Launikselle 24-vuotias poromies Aslak Jomppanen (s. 1882)'. Hän oli Kaapin-Jounin vaimon, Margareetan, vanhempi veli ja näin ollen tunsi Kaapin-Jounin hyvin. Onkin hyvin todennäköistä, että juuri Jomppasten talosta kehotettiin Launista lähteä etsimään Kaapin-Jounia.

1) Teksti. Aslak Jomppasen ${ }^{8}$ joikuesityksen teksti on hyvin pelkistetty. Ensin maini- 
taan kohteen nimi (Kápi-Jovna) ${ }^{9}$. Nimeä seuraavat partikkelit de ja jo. Tekstin loppuosa sisältää vain nun-nu, nun-nu -tavuja. On huomioitavaa, että nimen Kápi-Jovna tavujen painotus muuttuu laulettaessa. Paino siirtyy Ká-tavulta pi-tavulle (Ká-piJov-na) (ks. kaavio 1a).

Kaavio 1a. Kaapin-Jounin joiun teksti (Launis 1908, 632a).

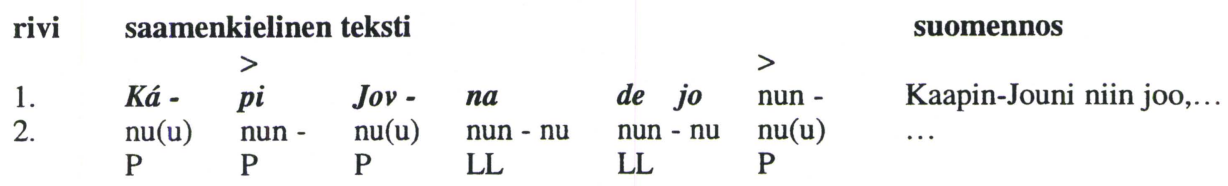

2) Melodia. Kaapin-Jounin joiun melodia koostuu kahdesta säeparista. Ensimmäinen säe (A) koostuu ylöspäisestä ja sitä seuraavasta alaspäisestä kvarttihypystä (g-c-g). Toinen säe (B) sisältää kolme d-säveltä (d-d-d). Launis on nuotintanut esityksestä kaksi säeparia. Toisessa säeparissa on erona ensimmäiseen Asäkeen rytmi sekä B-säkeen päättyminen d-sävelen sijasta c-säveleen. Melodiassa käytetyistä sävelistä saadaan sävelikkö g, c, d.

Seuraavassa nuottiesimerkissä on ylimmällä rivillä sävelikkö, vasemmalla Launiksen nuotinnos ja oikealla oma tulkintani. Jälkimmäinen on välttämätön, koska olen kerännyt toisintoja eri lähteistä ja vertailun mahdollistamiseksi melodiat on esitettävä yhtenäisessä muodossa. Olen kirjoittanut melodiat säkeittäin paradigmaattisesti jäsenneltynä ilman tahtiviivoja (ks. nuottiesimerkki 1).

Esimerkki 1. Kaapin-Jounin joiku (Launis 1908, 632a), käytetty sävelikkö ja kirjoittajan oma tulkinta melodiasta. Nuotinnos M. J.
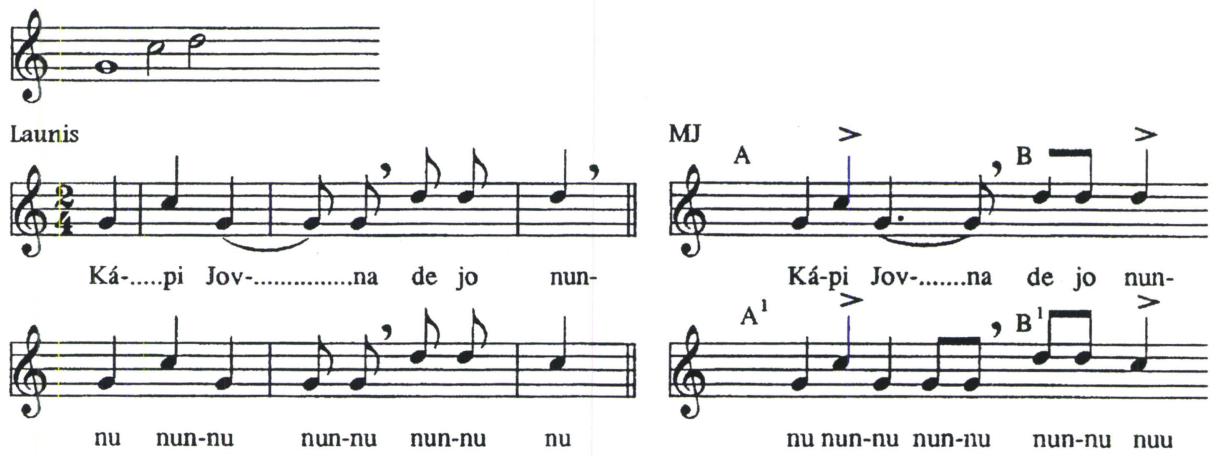
3) Metri. Metristä voidaan erottaa seuraavanlaisia päällekkäisiä kerrostumia: a) tekstin metri, b) melodian metri ja c) joikaajan oma metrinen pulssi.

Teksti jakautuu metrisesti kuusi iskua sisältäviin säkeisiin. Iskut sisältävät joko pitkiä sävelkestoja (esim. tavulla nuu) tai kahden lyhyen sävelkeston yhdistelmä (esim. tavuilla nun-nu). Kun pitkä kesto merkitään kirjaimella $P$ ja kahden lyhyen keston yhdistelmä kirjaimilla LL, voidaan tekstin metrinen kaava esittää seuraavassa muodossa: P P P LL LL P. On kuitenkin huomattava, että ensimmäisen säkeen viimeisen iskun tavu (nun-) on samalla myös toisen säkeen ensimmäiselle iskulle osuvan sanan (-nu) alku. Säkeet siis limittyvät toistensa kanssa kohdassa, jossa melodiassa on säeraja.

Melodian metriseksi perusyksiköksi olen valinnut kahden lyhyen sävelkeston yhdistelmän (LL) mittaisen yksikön ( $\$ \triangleright)$. Tämä siksi, että kaikissa toisinnoissa on samanlaisia tavuja ja näin eri melodiat saadaan metrisesti vertailukelpoisiksi. Melodiassa säepari jakautuu metrisesti kolmeen kahden iskun iskualaan, joista kaksi ensimmäistä kuuluu A-säkeeseen ja viimeinen B-säkeeseen $(2+2+2\rfloor d \downarrow d$ sd).

Joikaajan oman metrin mukaan aksentit tulevat toiselle ja kuudennelle iskulle. Tämä käy ilmi Launiksen nuotinnoksesta, jossa painollinen isku sijoitetaan aina tahdin ensimmäiselle iskulle. Aksenttiryhmiksi saadaan siis $4+2$. Huomaamme että jälkimmäinen aksentti osuu melodian viimeiselle sävelelle ja näin ollen melodian ensimmäinen sävel on painoltaan heikko. Tämä aksentointi sopii hyvin tavujen jakautumisen kanssa.

4) Muoto. Launis ei yleensä merkinnyt muistiin kuin joikujen ensimmäiset säeparit. Tämä ei kuitenkaan merkitse sitä, etteivätkö hänelle esitetyt joiut olisi pidempiä ja sisältäneet enemmän tekstiä sekä melodista ja rytmistä variaatiota ${ }^{10}$. Kahden säeparin kokonaisuus on kuitenkin tämän toisinnon peruselementti, jota kertaamalla saadaan tarvittaessa pidempi kokonaisuus (ks. kaavio 1b).

Kaavio 1 b. Kaapin-Jounin joiun kahden säeparin kokonaisuus.

\begin{tabular}{|c|c|c|}
\hline & säkeet & iskualat \\
\hline 1. & A & $3(22+2)$ \\
\hline 2. & A & $3(22+2)$ \\
\hline
\end{tabular}

\subsection{Menesjärven Matin esitys Kaapin-Jounin joiusta}

Joiun n:o. 653b joikasi Launikselle 30-vuotias Inarin Menesjärvellä asunut kalastaja Matti ${ }^{\prime}$. Kaiken kaikkiaan Launiksen kokoelmasta löytyy 53 Matin joikaamaa 
melodiaa eli häntäkin voidaan pitää kokoelman kannalta merkittävänä joikaajana.

1) Teksti. Joiun teksti koostuu edellisen esimerkin tapaan kohteen nimestä (KápiJovna) ja nun-nu-tavuista.

Kaavio 2a. Kaapin-Jounin joiun teksti (Launis 1908, 632b).

rivi saamenkielinen teksti

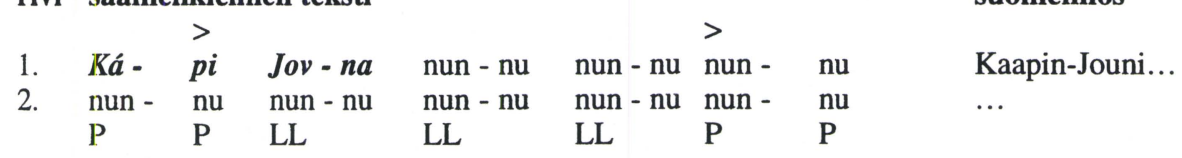

2) Melodia. Melodia koostuu säeparista, joka kerrataan kahdesti. A-säkeessä on tuttu kvarttihyppy ylös ja alas. B-säe alkaa g-säveleltä, josta hypätään d-sävelelle ja tullaan c:n kautta takaisin perussävelelle. Tämän toisinnon sävelikkö on myös g, c, d.

Esimerkki 2. Kaapin-Jounin joiku (Launis 1908, 632b), käytetty sävelikkö ja kirjoittajan oma tulkinta melodiasta. Nuotinnos M. J.

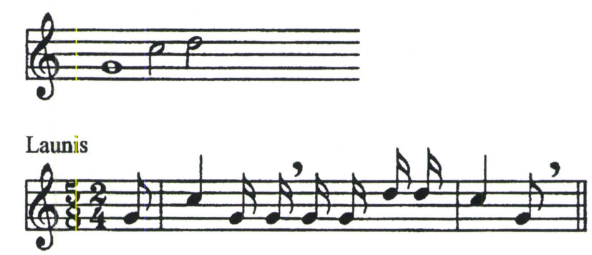

Ká-.....pi Jov-na nun-nu nun-nu nun-nu

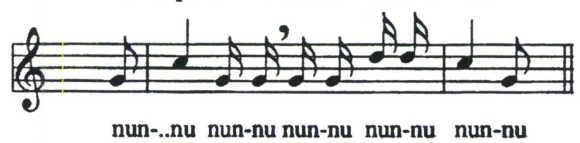

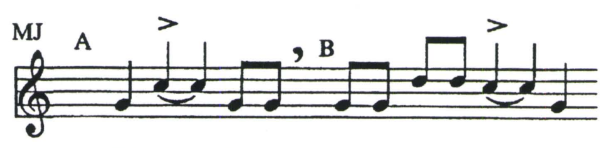

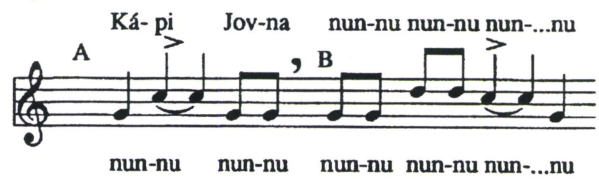

3) Metri. Teksti jakautuu metrisesti seitsemän iskua sisältäviin säkeisiin. Metriseksi kaavaksi saadaan P P LL LL LL P P.

Melodiassa säepari jakautuu metrisesti kahteen iskualaan. A säe sisältää neljä iskua kuten Aslak Jomppasen esityksessä. Tämän toisinnon esittäjä on jakanut kuitenkin rytmiä eri lailla. Hän on pidentänyt säkeen toista säveltä ja näin muodostuu keskipitkä rytmi. Vastaavasti hän on lyhentänyt neljättä säveltä. B-säe on viisi-iskuinen eli yhden iskun A-säettä pidempi. Ensimmäisen iskun jälkeen seuraa jälleen keskipitkä rytmi.

$$
(4+5 y \rho \cos \rho \rho d \rho) \cdot{ }^{12}
$$


Joikaajan oman metrin mukaan aksentit tulevat toiselle ja kuudennelle iskulle ja ne vastaavat melodian aksentteja. Aksenttiryhmiksi saadaan 4+3.

4) Muoto. Joiun perusyksikkö on kaksi säeparia, jotka ovat identtiset keskenään.

Kaavio $2 b$. Kaapin-Jounin joiun kahden säeparin kokonaisuus.

\begin{tabular}{llll} 
& \multicolumn{2}{r}{ säkeet } & iskut \\
1. & A & B & $4+5(1+2+11+1+2+1)$ \\
2. & A & B & $4+5(1+2+11+1+2+1)$
\end{tabular}

\section{Kaapin-Jounin joiun toisinnot Ala-Könni-kokoelmassa}

\subsection{Uula Aikion esittämä isän joiku 1 (A-K 1)}

Erkki Ala-Könni matkusti Inarissa, Utsjoella ja Enontekiöllä vuosina 1961 ja 1963. Kaiken kaikkiaan hän tallensi 451 joikua näiltä paikkakunnilta. Kaapin-Jounin joiusta hänelle tarttui neljä toisintoa. Kolme Kaapin-Jounin pojan Uula Aikion esittämänä sekä yksi Enontekiön Palojärvellä asuneen Antti Proksin (s. 1911) esittämänä.

1) Teksti. Uula Aikion esittämän isän joiun'13 tekstissä kuvastuu, kuinka joiun ymmärtämiseen tarvitaan sekä kohteen henkilöhistorian että tämän joikaamistavan tuntemista. Ensinnäkin Kaapin-Jounin siskonpojan, Jouni Maggan mukaan, Uula Aikiolla oli joikatessaan usein tapana asettua joikattavan hahmoon ja käyttää sekä yksikön 1. että 3. persoonaa kuvaamaan samaa henkilöäi4. Ilman tätä tietoa on hankala ymmärtää, että ensimmäisen tekstirivin áddjáis on sama Kaapin-Jouni, josta puhutaan viidennellä, kuudennella ja yhdeksännellä rivillä minä-muodossa.

Toiseksi joiussa kerrotaan kuinka Kaapin-Jouni kuului Kyrön paliskuntaan, ja kuinka hän aikoinaan mahtaili olevansa "koko Inarin mahtavin ja rikkain poromies". Suuruutta korostetaan vielä väittämällä koko Inaria yhdeksi suureksi palkiseksi, jonka päämies hän oli. Mutta lopuksi paljastetaan, että rikkaus oli itse asiassa kadonnut jo aikoja sitten, ja nyt vain muistellaan menneitä suuruudenaikoja.

Uula Aikion esittämät joiut ovat mielenkiintoisia myös siksi, että niissä kuvastuu pojan suhde isäänsä. Uula ei esimerkiksi mainitse kertaakaan Kaapin-Jounia nimeltä vaan puhuu pelkästään isästään tai käyttää sanaa áddjá. 
Kaavio 3a. Kaapin-Jounin joiun teksti. Transkriptio M. J. ja Annukka Hirvasvuopio.

\begin{tabular}{|c|c|c|c|c|c|c|c|}
\hline rivi & saame & nkieli & en teksti ${ }^{16}$ & & & & suomennos \\
\hline 1. & $>$ & & & & $>$ & & \\
\hline 2. $\boldsymbol{K} \boldsymbol{y}-\boldsymbol{r} \ddot{\boldsymbol{\theta}}$ & bálg - & ges & ádd-já & $d a(h) t$ lei & noo & noo & Kyrön palkisessa isoisä oli... \\
\hline $\begin{array}{l}\text { 3. non - no } \\
\text { 4. }\end{array}$ & noo & noo & non - no & noo - noo & noo & noo & $\ldots$ \\
\hline 5. Mun $d a(h) t$ & lean & joo & $A$ - nár & bálg - ges & oai - & $v i$ & $\begin{array}{l}\text { Minä se olen jo Inarin palkisen } \\
\text { pää... }\end{array}$ \\
\hline 6. Do-lin & áig - & $g i$ & led-jen & lol - lo & 100 & 100 & Entisinä aikoina, olin... \\
\hline $\begin{array}{l}\text { 7. } 101-10 \\
8 .\end{array}$ & 100 & loo & lol - lo & lol - lo & 100 & 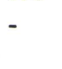 & $\ldots$ \\
\hline $\begin{array}{l}\text { 9. De mun } \\
\text { 10. lol - lo }\end{array}$ & $\begin{array}{l}\text { led }- \\
\text { loo }\end{array}$ & $\begin{array}{l}\text { jen } \\
\text { loo }\end{array}$ & $\begin{array}{l}\text { juoig - ga- } \\
\text { lol - la }\end{array}$ & $\begin{array}{l}\text { dan juo } \\
\text { lol - la }\end{array}$ & $\begin{array}{l}\text { vel - } \\
\text { loo }\end{array}$ & $\begin{array}{l}\text { lea } \\
\text { loo }\end{array}$ & näin minä olin joikaillut... \\
\hline 11. lol - lo & loo & loo & lol - lo & lol - lo & 100 & 100 & $\cdots$ \\
\hline 12. $\mathrm{LL}$ & $P$ & $\mathbf{P}$ & LL & LL & $\mathbf{P}$ & $\mathbf{P}$ & \\
\hline
\end{tabular}

2) Melodia. Melodia koostuu kahden säeparin kokonaisuudesta, jota kerrataan. Säkeessä A on tuttu kvarttiaihe (g-c-g). B-säkeessä hypätään korkeammalle esäveleen saakka ja säeparin kertauksen $b^{1}$ :ssä käydään jopa $f-j a$ f\#-sävelillä. Sävelikkö on siis g, c, e, f, f\#.

Esimerkki 3a. Kaapin-Jounin joiku 1. Oikealla sävelikkö. Esittäjä: Uula Aikio Äänitetty 1961 A-K 541. Soiva säveltaso joiun alussa: $\mathrm{g}=\mathrm{c}$, joiun lopussa $\mathrm{g}=\mathrm{c \#}$. Nuotinnos M. J.

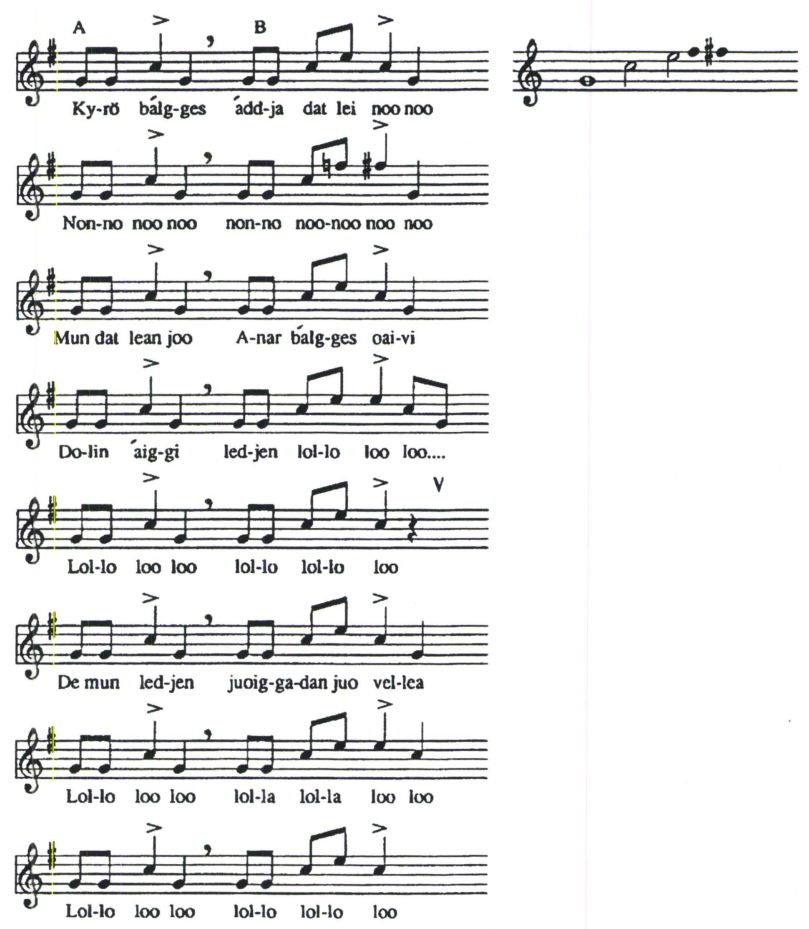


3) Metri. Teksti jakautuu metrisesti seitsemään iskuun ja pohjakaavaksi saadaan LL P P LL LL P P. Melodiassa säepari jakautuu metrisesti kahteen iskualaan. A-säkeessä on kolme iskua ja B-säkeessä neljä, eli jälleen kerran se on yhden iskun pidempi

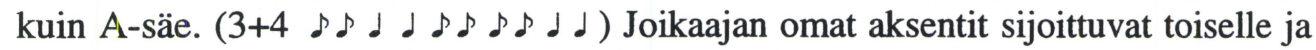
kuudennelle iskulle. Aksenttiryhmiksi saadaan 4+3.

4) Sävelasteiden toteuttaminen. Koska analysoitavana on tällä kertaa nauhoitettu esitys, saadaan melodian analyysiin tarkennusta. Perinteisesti melodiaan liittyviä hienovaraisia yksityiskohtia kutsutaan esimerkiksi korusäveliksi tai kansanomaisessa musiikissa niekuiksi. Korusävelet liittyvät kuitenkin länsimaiseen nuottikirjoitusperinteeseen, jonka piirissä kirjoitettiin käytännön syistä muistiin vähemmän ja yksinkertaisemmin kuin miltä soiva musiikki todellisuudessa kuulosti. Nuotinnetun runkomelodian koristeleminen tarkoittaa siis suullisen tradition käytäntöjen lisäämisestä kirjalliseen abstraktioon.

Perinteisiin joikuihin ei saamelaisten keskuudessa kuitenkaan liity kirjallista traditiota ${ }^{17}$. Ei ole olemassa mitään teoreettista, absoluuttista, elävästä tilanteesta irrallaan olevaa joikuesitystä. Nuotinnokset joikumelodioista ja niiden korusävelet ovat nuotintajien tulkintoja. Mielestäni joiuissa ei voida puhua ylimääräisistä koristeista tai asteikkoon kuulumattomista sävelistä, vaan kaikki melodian sävelet ovat pikemminkin sävelikön eri asteiden toteutusta.

Kuunneltaessa melodiaa hitaalla nopeudella saadaan kuitenkin esille yksityiskohtia, jotka normaalinopeudella saattavat jäädä huomiotta liian hienovaraisina yksityiskohtina. Nämä yksityiskohdat kuitenkin erottuvat myös normaalinopeudella kun ne on kerran huomannut. Pienillä nyanssieroilla voidaan joiussa tehdä muutoksia, jotka jäävät merkityksettömiksi joikua ja sen yhteyksiä tuntemattomille (ks. Kantola 1981, 46). Seuraavassa analysoin esimerkki 3a:n yhden säeparin melodian sävelasteiden käytännön toteutusta (ks. esim. 3b).

Sävelestä toiseen liikutaan lähes aina liukumalla. Ylöspäinen asteittainen liike tai hyppy melodiassa toteutetaan aina liukumalla alhaaltapäin. Perussävelelle tehtävä alaspäinen hyppy liu'utetaan alapuolisen johtosävelen kautta. Perussävel g:lle johtaa siis sekä ala- että yläpuolinen puolisävelaskel (f\#-g, ab-g). C-sävelelle on vain alapuolinen johtosävel (h-c). E:lle tullaan liukumalla g:Itä. E:tä venytetään myös ylöspäin $\mathrm{f}$-säveleen ja jopa $\mathrm{f \# -säveleen} \mathrm{saakka.} \mathrm{Puolisävelaskelkuviot} \mathrm{esiintyvät}$ eräänlaisena laajana vibratona ( $h-c-h-c)$. Koska sävelikön asteita käsitellään aina samoin, on kyse joikaajan henkilökohtaisesta tyylistä (ks. esim. 3c).

Joikaaja rytmittää pitkät sävelet kolmeen'1 . Tämä tapahtuu joko rytmisesti käyttämällä hyväksi sanan äänteitä tai melodisesti käymällä puolisävelaskeleen tai kokosävelaskeleen päässä pääsävelen alapuolella (g-f\#-g, d-c\#-d, e-d-e, h-a-h). Jälkimmäinen muistuttaa läheisesti vibratoa, mutta on joka tapauksessa täysin säännönmukaisesti samanlainen aina samalla tekstisäkeen kohdalla riippumatta siitä, 
onko tällä kohdalla sana vai non-no-tavu.

Kahteen jakautuvilla iskuilla (LL) joikaaja jakaa kummankin iskun rytmisesti kahteen. Tämä tapahtuu siten, että ensimmäisen sävelen kohdalla liu'utaan vokaalilla jo seuraavaan säveleen ja vasta tämän jälkeen lausutaan konsonantti. Näin pikkusanoilla nonnotteluun syntyy hyvin elävä 16-osarytmi, jossa vuorottelevat painollinen pääisku ja painoton isku, jolla liu'utaan.

Esimerkki 3b. Sävelikön asteiden toteuttaminen.

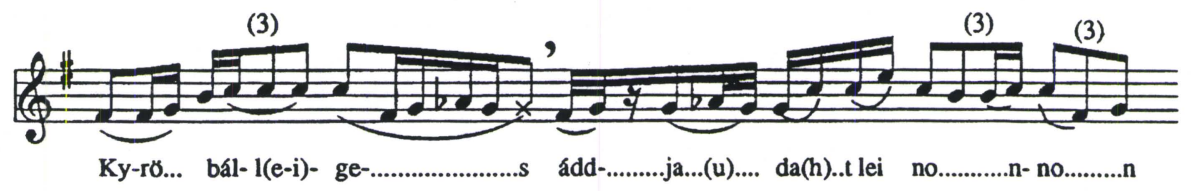

Esimerkki 3c. Sävelikkö, jossa on huomioitu sävelikön asteiden toteuttaminen.

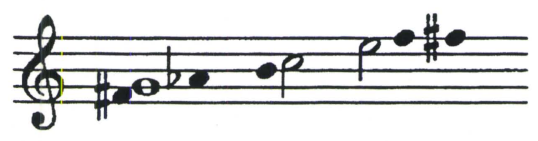

5) Muoto. Esityksen muotorakenne on jonomainen ( $a b$ ab $\left.{ }_{1} ..\right)$. Joikaaja lopettaa säkeistöt kummallakin kertaa säeparin ab jälkeen.

Kaavio 3b. Kaapin-Jounin joiun melodiasäkeet.

\begin{tabular}{|c|c|c|}
\hline & säkeet & iskut \\
\hline 1. & $a \quad b$ & $3+4$ \\
\hline & $a \quad b^{1}$ & $3+4$ \\
\hline & $\begin{array}{lll}a & b\end{array}$ & $3+4$ \\
\hline & $\begin{array}{ll}a & b^{1}\end{array}$ & $3+4$ \\
\hline & $a \quad b$ & $3+3$ \\
\hline & $a \quad b$ & $3+4$ \\
\hline & $\begin{array}{ll}a & b^{1}\end{array}$ & $3+4$ \\
\hline & $a \quad b$ & $3+4$ \\
\hline
\end{tabular}

6) Hengitys. Esityksen hengitys on joiulle tyypillistä. Joikua jatketaan niin kauan kuin ilmaa riittää, ja sen loputtua katkaistaan joiku ja hengitetään. Hengitystauot 
eivät välttämättä noudata säerajoja (ks. esim. Kantola 1984, 40-41). Uula Aikio hengittää 34 sekuntia kestävän joiun aikana kahdesti: $21 \mathrm{~s}$. kohdalla sekä $34 \mathrm{~s}$. kohdalla. Muut amplitudikuvaajassa 1 näkyvät äänen katkeamiset tapahtuvat soinnittomien konsonanttien edellä tai kaksoiskonsonanttien välissä.

Amplitudikuvaaja 1. A-K 541/1.

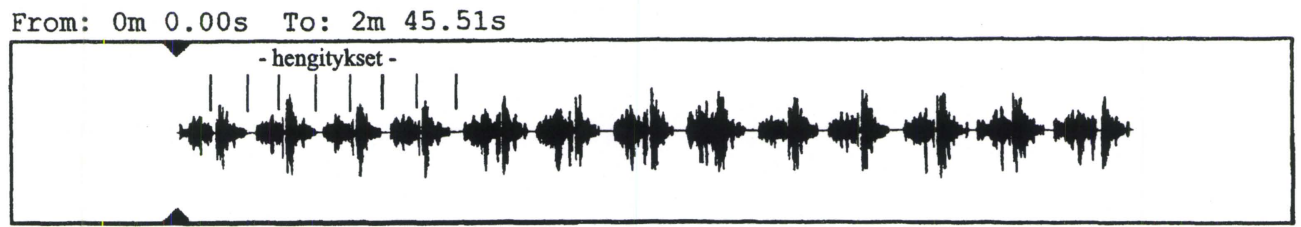

\subsection{Uula Aikion esittämä isän joiku 2 (A-K 2)}

1) Teksti. Tämän toisinnon'19 tekstinä on kaksi lausetta: "isä se oli" ja "se joo vielä oli". Uula kertoo joiusta seuraavanlaisesti:

"Isäni oli tuolla Viipastunturissa. Omia, isän tekemiä joikuja".

Tällä kertaa joiku vaikuttaa paljon henkilökohtaisemmalta. Kyse on ensisijaisesti joikaajan isästä eikä koko seudun tuntemasta suuresta ja rikkaasta poromiehestä.

Kaavio 4a. Kaapin-Jounin joiun teksti. Transkriptio M. J. ja Annukka Hirvasvuopio. rivi saamenkielinen teksti suomennos

\begin{tabular}{|c|c|c|c|c|c|c|c|c|}
\hline & & $>$ & & & & $>$ & & \\
\hline 1. & Áhè - èi & dat & lea & lol - lol & lol - lol & 100 & 100 & Isä se oli... \\
\hline 2. & lol - lol & 100 & 100 & lol - lol & lol - lol & 100 & 100 & $\cdots$ \\
\hline 3. & lol - lol & 100 & 100 & lol - lol & lol - lol & 100 & 100 & $\ldots$ \\
\hline
\end{tabular}

$\begin{array}{lllllllll}\text { 4. } & \text { De juo } & \text { vel }- & \text { lea } & \text { non - non } & \text { non - non } & \text { noo } & \text { noo } & \text { Se joo vielä oli... } \\ \text { 5. } & \text { non - non } & \text { noo } & \text { noo } & \text { non - non } & \text { nan - nan } & \text { naa } & \text { noo } & \ldots \\ \text { 6. } & \text { non - non } & \text { naa } & \text { loo } & \text { lol - lol } & \text { lol - lol } & \text { loo } & \text { loo } & \ldots \\ & \text { LL } & \text { P } & \text { P } & \text { LL } & \text { LL } & \text { P } & \text { P } & \end{array}$

2) Melodia. Toisinnon melodia on lähes täsmälleen edellisen toisinnon kaltainen. Bsäkeessä Uula ei nosta ääntä f\#-säveleen asti vaan jää f-sävelelle.

Esimerkki 4a. Kaapin-Jounin joiku 2. Esittäjä: Uula Aikio Äänitetty 1961 A-K 541. Soiva säveltaso joiun alussa: $\mathrm{g}=\mathrm{b}$, joiun lopussa $\mathrm{g}=\mathrm{h}$. Nuotinnos M. J. 
3) Metri. Metrisesti teksti jakautuu seitsemään iskuun. Kaava on LL P P LL LL P P eli täsmälleen sama kuin aiemmassa toisinnossa.
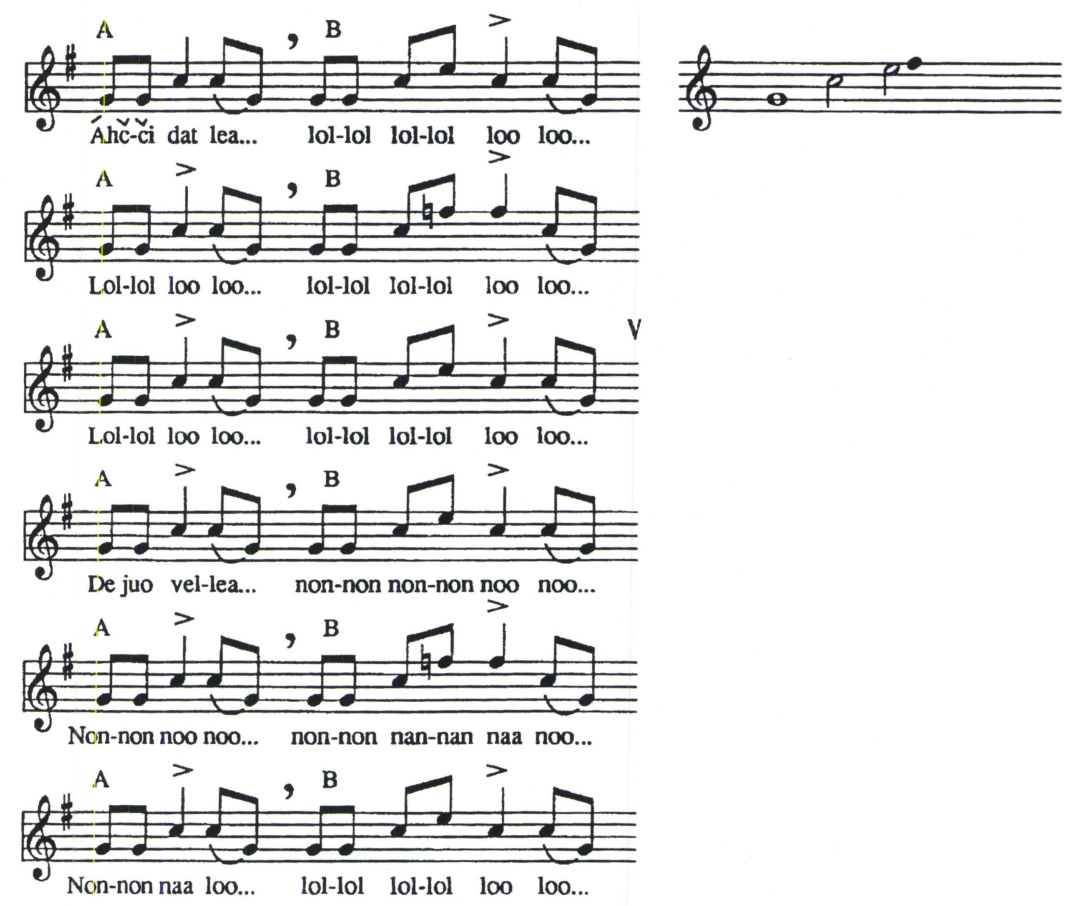

Melodian metri on myös edellisen toisinnon kaltainen ja se jakautuu seitsemäksi iskuksi $(3+4 \& \triangleright d \downarrow \triangleright \triangleright \triangleright \triangleright d \downarrow)$. Joikaajan omat aksentit ovat 2. ja 6. iskulla. Aksenttiryhmiksi saadaan jälleen 4+3.

4) Sävelasteiden toteuttaminen. Perussävelelle tullaan aina alapuolisen johtosävelen kautta. C-sävelelle tullaan puolestaan joko alhaaltapäin liukumalla g:Itä tai ylhäältäpäin h:n kautta. Pikkusanat rytmitetään glissandojen ja l-kaksoiskonsonantin avulla 16-osakuvioiksi. Pitkät sävelet jaetaan kolmeen ja rytmitetään alapuolisella johtosävelellä.

Esimerkki $4 b$. Sävelikön asteiden toteuttaminen.

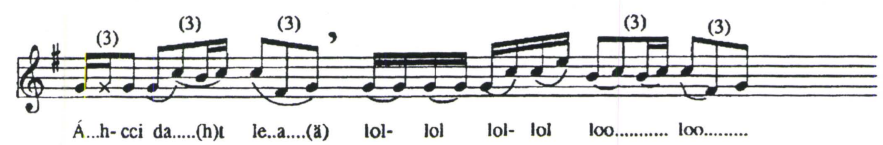


Esimerkki $4 c$. Sävelikkö, jossa on huomioitu sävelikön asteiden toteuttaminen.

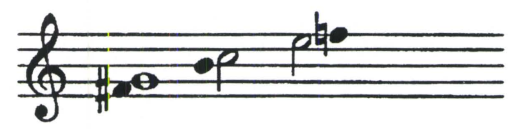

5) Muoto. Joiku jakautuu kahteen säkeistöön, joissa kummassakin on kolme säeparia $\left(\mathrm{AB}-\mathrm{AB}^{1}-\mathrm{AB}\right)$.

Kaavio 4b. Kaapin-Jounin joiun melodiasäkeet.

$\begin{array}{llll}\text { säkeet } & \text { iskut } \\ \text { 1. } & \text { A } & \text { B } & 3+4 \\ \text { 2. } & \text { A } & \text { B } 1 & 3+4 \\ \text { 3. } & \text { A } & \text { B } & 3+4 \\ & & & \\ \text { 4. } & \text { A } & \text { B } & 3+4 \\ \text { 5. } & \text { A } & \text { B } & 3+4 \\ \text { 6. } & \text { A } & \text { B } & 3+4\end{array}$

6) Hengitys. Joiussa on yksi hengityspaikka $13 \mathrm{~s}$. kohdalla. Kokonaiskesto on $25 \mathrm{~s}$. amplitudikuvaaja 2. A-K 541/2.

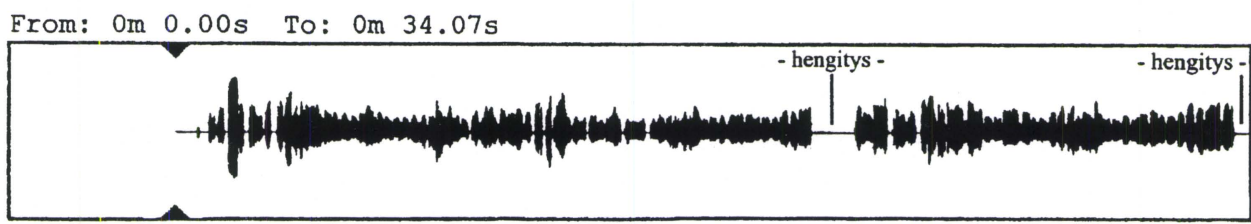

\subsection{Enontekiöläisen Heikin-Niilan tekemä joiku Kaapin-Jounista (A-K 3)}

Myös tämän toisinnon joikasi Kaapin-Jounin Uula. Hän kertoi tämän olevan enontekiöläisen Heikin-Niilan tekemä joiku²0. 
'Tämän joikas Heikin-Niila ennen, ko me olimme siellä Jaurastunturisa isän musikkiporoista, että sarvet ko oli taaksepäin, että musikkinaitit. Heikin-Niilan, tekemä, Magga-Niilan, Enontekiöltä."

1) Teksti. Joiussa kuvaillaan Kaapin-Jounin komeita mustia hirvaita, joita pidettiin erityisen arvokkaina vetoporoina. Porotokan juoksun tuottama ääni, koparoiden kopse viittaa siihen että näitä mustia naiteja oli paljon, aivan tokaksi asti ja että Kaapin-Jouni oli todella rikas. Lopuksi Kaapin-Jounin Uula lisää vielä maininnan alkuperäisestä joikaajasta: "tämän oli joikaillut Heikin-Niila".

Kaavio 5a. Kaapin-Jounin joiun teksti. Transkriptio M. J. ja Annukka Hirvasvuopio.

rivi saamenkielinen teksti

1.

2. 100

3. Maa .

$$
\text { lo - } 100
$$$$
\text { selg - gis }
$$

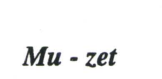

4. 100

5. 100

6.

7. noo

8. noo

9. Heiak -

10. 100

11. lou

12. Gaz -

13. Maa -

14. 100

P

$$
\text { lool - la }
$$$$
100
$$

$$
M u \text { - zet }
$$$$
\text { noo - noo }
$$$$
\text { dat lei }
$$$$
\text { ka juo }
$$

lool - lo

lool - lo

$\begin{array}{lll}\text { njáid }- \text { di } & \text { vel } & \text { lea } \\ \text { lool - loo } & \text { loo } & \text { loo } \\ \text { gaz-zu- } & \text { dee } & \text { juo }\end{array}$

lool - la
lool - lo

100
$100-1 a$

100

loo//

$\begin{array}{lll}\text { njáid }- \text { di } & \text { noo } & \text { noo } \\ \text { noo - noo } & \text { noo } & \text { noo } \\ \text { juoig - ga- } & \text { dan } & \text { juo } \\ \text { Nii }- \text { las } & \text { loo } & \text { loo } \\ \text { lool - lo } & \text { lou } & \text { lou } \\ \text { lool - la } & \text { loo } & \text { loo/l }\end{array}$

2) Melodia. Tässä toisinnossa sävelikkö on edellisiä hieman tiheämpi (g-a-h-c-e). Joikaaja täyttää a-säkeen ylöspäisen kvarttihypyn (g-c) asteittaisessa liikkeellä (g-ah-c). B-säe alkaa myös poikkeuksellisesti sävelikön toiselta asteelta eikä ensimmäiseltä kuten muissa toisinnoissa. Tämän lisäksi a sävelen toiston sijaan seuraava sävel on korvattu sekä ylä- että alapuolisella sävelellä (h-g), jonka jälkeen hypätään ensin kvintti ylös ja seksti alas (a-e-g). 
Esimerkki 5a. Kaapin-Jounin joiku 3 ja sävelikkö. Esittäjä: Uula Aikio Äänitetty 1961 A-K 541. Soiva säveltaso joiun alussa: $g=d$, joiun lopussa $g=d$. Nuotinnos M. J.

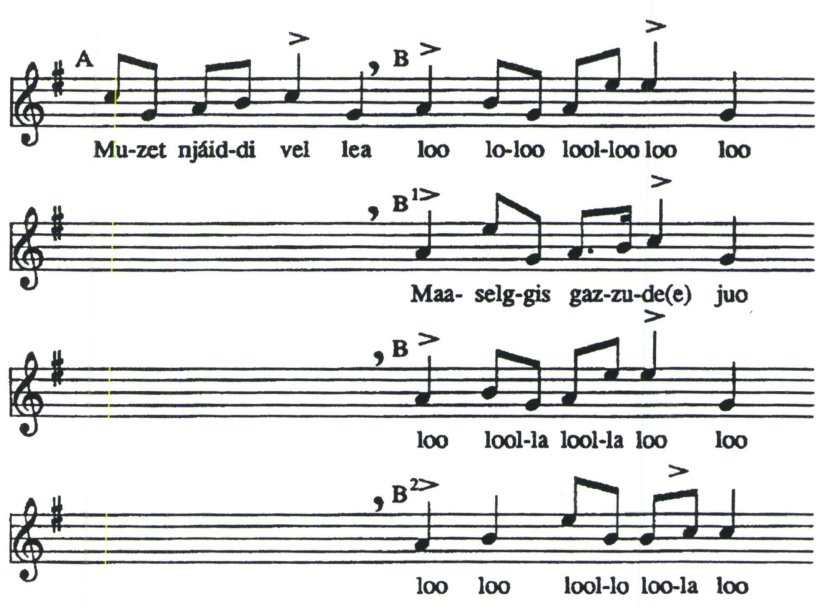

3) Metri. Teksti jakautuu metrisesti viisi-iskuisiin säkeisiin (P LL LL P P), joista muodostuu kolmen säkeistön kokonaisuus. Joiun kaksi ensimmäistä säkeistöä alkavat kuitenkin neli-iskuisilla säkeellä. Painot ovat ensimmäisellä ja neljännellä iskulla ja ne osuvat pitkän tavun kohdalle.

Melodian metri on pääosin viisi-iskuinen. Tosin kahdella rivillä säkeistöjen aluis-

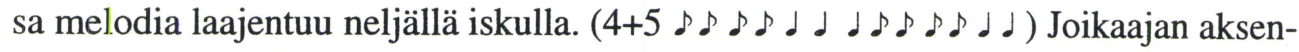
tit ovat 1. ja 4. iskuilla. Aksenttiryhmksi saadaan siis $3+2$.

4) Sävelikön asteiden toteuttaminen. Sävelestä toiseen liikutaan liukumalla. Ylöspäinen asteittainen liike tai hyppy melodiassa toteutetaan aina liukumalla alhaaltapäin. Perussävelelle tehtävä alaspäinen hyppy liu'utetaan myöskin. Tämän lisäksi käydään perussävelen alapuolisella sävelellä $\mathrm{f \# .}$

Joikaaja rytmittää pitkät sävelet $(\mathrm{P})$ kolmeen. Tämä tapahtuu joko käyttämällä hyväksi sanan äänteitä (muu-ze-(h)t, ${ }^{23}$ selg-gi-s) tai melodisesti käymällä puolisävelaskeleen tai kokosävelaskeleen päässä pääsävelen alapuolella (g-f\#-g, d-c\#-d, ed-e, h-a-h). Jälkimmäinen muistuttaa läheisesti vibratoa, mutta on joka tapauksessa täysin säännönmukaisesti samanlainen aina samalla tekstisäkeen kohdalla.

Kahteen jakautuvilla iskuilla (LL) joikaaja jakaa kummankin iskun rytmisesti kahteen. Tämä tapahtuu siten, että ensimmäisen sävelen kohdalla liu'utaan vokaalilla jo seuraavaan säveleen ja vasta tämän jälkeen lausutaan konsonantti. Näin nonnotteluun syntyy hyvin elävä 16-osarytmi, jossa vuorottelevat painollinen pääisku ja painoton isku, jolla liu'utaan.

Esimerkki $5 b$. Sävelikön asteiden toteuttaminen. 
5) Muoto. Melodiasäkeet noudattavat tekstisäkeitä. Esitys koostuu pääosin B-säkeistä. A-säe esiintyy vain kaksi kertaa kahden ensimmäisen säkeistön alussa.

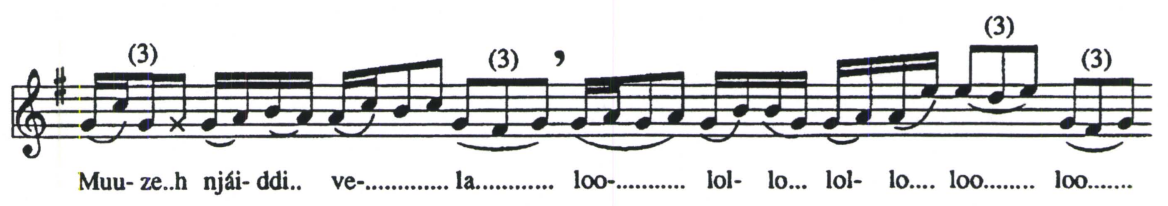

Kaavio 5b. Kaapin-Jounin joiun melodiasäkeet.

\begin{tabular}{|c|c|c|}
\hline \multicolumn{3}{|c|}{ säkeet } \\
\hline 1. & A & B \\
\hline 2. & & B \\
\hline 3. & & B \\
\hline 4. & & B \\
\hline
\end{tabular}

$\begin{array}{lllr}\text { 5. } & \text { A } & \text { B } & 4+5 \\ 6 . & & \text { B } & 5 \\ 7 . & & \text { B } & 5 \\ 8 . & & \text { B } & 5 \\ 9 . & & \text { B } & 5\end{array}$

$\begin{array}{lll}10 . & \text { B } & 5 \\ 11 . & \text { B } & 5 \\ 12 . & \text { B } & 5\end{array}$

6) Hengitys. Myös Amplitudikuvaaja osoittaa selvästi esityksen jakautumisen kolmeen osaan, joiden välillä hengitetään. Hengitykset ovat 14 s., 30 s. ja 39 s. kohdalla.

Amplitudikuvaaja 3. A-K 541/3.

3.4. Enontekiöläisen Antti Proksin tekemä joiku Kaapin-Jounista (A-K 4)

From: Om 0.00s To: Om 39.10s

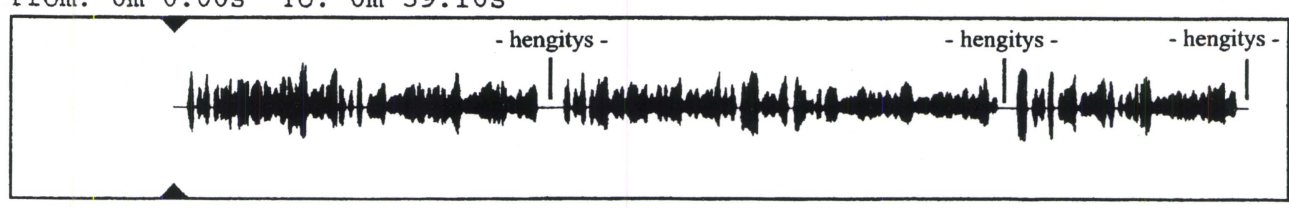


Kaksi vuotta edellisten äänitysten tekemisen jälkeen Ala-Könni matkusti Karl Nickulin kanssa Enontekiölle, jossa he tallensivat jälleen yhden toisinnon KaapinJounin joiusta ${ }^{24}$. Joikaajana oli tällä kertaa vuonna 1911 syntynyt Antti Proksi Palojärveltä. Kun Kaapin-Jouni oli ollut Launiksen parhain informantti, oli Antti Proksi tätä Ala-Könnille. Proksilta on tallennettu kaiken kaikkiaan 79 joikua, mikä muodostaa noin viidenneksen koko Ala-Könni-kokoelman joikumateriaalista.

1) Teksti. Tässä toisinnossa ei mainita muuta kuin Kaapin-Jounin nimi. Kun Nickul kysyy joikaajalta selitystä joikuun, Antti Proksi vastaa, ettei Kaapin-Jounia tunnettu Enontekiöllä kovin hyvin. Tekstin sijaan tässä joiussa lol-lo- ja nun-nutavut ovat pääosassa. Kummassakin joiun osassa joikaaja ikään kuin hakee sopivaa tavua kunnes suurin piirtein puolessa välissä päätyy toistamaan samaa tavua. Tavun ohella tärkeää tuntuu olevan kokonaisäänenväri. Välillä on jopa hieman vaikea erottaa mitä tavua joikaaja käyttää.

Kaavio 6a. Kaapin-Jounin joiun teksti. Transkriptio M. J. ja Annukka Hirvasvuopio.

Rivi Saamenkielinen teksti

1. $\mathrm{Na}+\mathrm{naa}$

2. Nun - nun nun - nun nuu

3. Kaa - pin Jou $-n i \quad$ nun

4. Nun - nuu lol-lol $\quad$ loo

5. Lul - lul lul - lul luu

6. Kaa-pin Jou $-n i \quad$ laa

7. Nun - nun

8. Nun - nun

9. Nun - nun

10. Nun - nun

11. Nun - nun

12. Hoo,

13. Lei - joo

14. Kaa - pin

15. Kaa - pin

16. Lul - lul

17. Lul - lul

18. Lul - lul

19. Lul - lul

20. Lul - lul

21. Lul - lul

LI
Suomennos

$\gg \quad>$

\begin{tabular}{|c|c|c|c|}
\hline $\begin{array}{l}\text { nuu - u } \\
\text { nuu - u }\end{array}$ & nuu & nuu - u & $\begin{array}{l}\ldots \\
\text { Kaapin-Jouni }\end{array}$ \\
\hline lou - o & 100 & lou - o & $\ldots$ \\
\hline luu - u & & & $\ldots$ \\
\hline jou - go & nuu & nuu - u & Kaapin-Jouni \\
\hline lou - o & & & $\ldots$ \\
\hline nuu - u & noo & Nun - nun & $\ldots$ \\
\hline nuu - u & noo & Nun - nun & $\ldots$ \\
\hline nuu - u & noo & Nun - nun & $\ldots$ \\
\hline nuu - u & noo & Nun// & $\begin{array}{l}\cdots \\
\ldots\end{array}$ \\
\hline $100-0$ & 100 & $100-0$ & $\ldots$ \\
\hline
\end{tabular}

noo

noo - o

Kaapin - Jouni

joo go luu

luu - $\mathrm{u}$

Kaapin - Jouni

luu - $\mathrm{u} \quad$ luu

luu - u

luu - u laa luu - u

luu $-\mathrm{u} \quad$ laa

luu - $\mathbf{u}$

luu $-\mathrm{u} \quad$ laa

luu - u

luu - u laa

luu $-\mathrm{u} \quad$ laa

luu - u

lul

LL

P

LL

2) Melodia. Tämän toisinnon melodia erottuu eniten muista toisinnoista. Tämä on myös ainoa toisinto, jossa liikutaan laajasti sekä perussävelen ylä- että alapuolella. 
Korkeimmat sävelet on ikään kuin heitetty oktaavilla alas. Tutun kvarttimotiivin (gc-g) eteen on lisätty alapuolinen sävel e sen jälkeen puolestaan sekä alapuolinen sävel e että c. B-säkeen motiiviissa on häntä, jossa kerrataan kaksi edellistä säveltä matalammalta.

Esimerkki 6a. Kaapin-Jounin joiku. Esittäjä: Antti Proksi Äänitetty 1961 A-K 541. Soiva säveltaso joiun alussa: $\mathrm{g}=\mathrm{b}$, joiun lopussa $\mathrm{g}=\mathrm{es}$. Nuotinnos M. J.

3) Metri. Teksti jakautuu metrisesti kuuteen iskuun, joiden kaavaksi saadaan LL LL

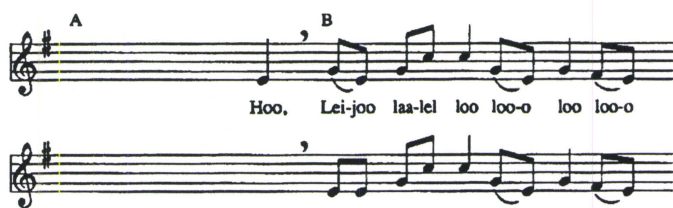

Kaa-pin Jou-ni noo noo-o noo noo-
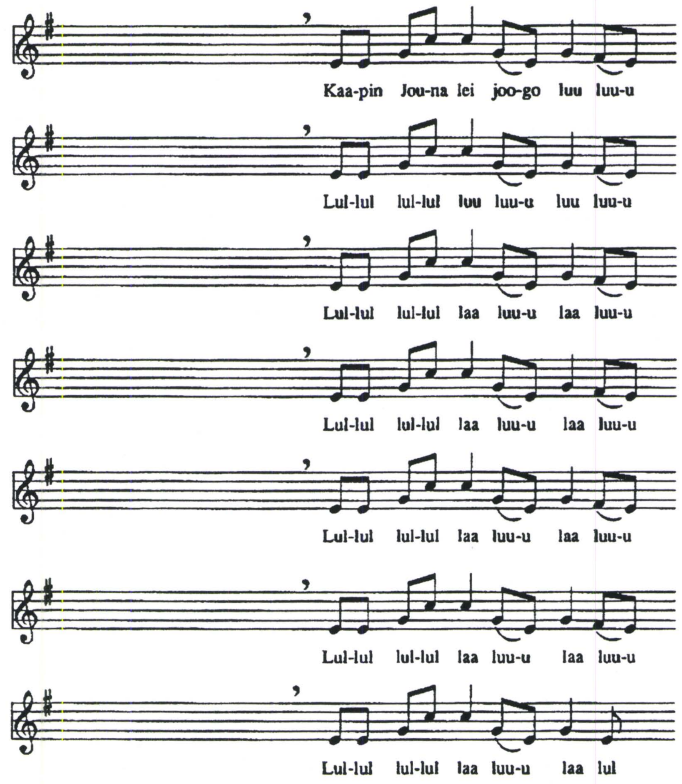

P LL P LL. Melodia jakaantuu säkeittäin siten, että A-säkeessä on neljä iskua ja Bsäkeessä kuusi iskua. Joiun alussa nämä esitetään peräkkäin neljä kertaa, jolloin saa-

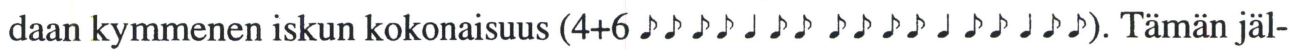
keen melodiassa esiintyy käytännössä vain B-säkeitä. Joikaajan oma aksentointi asettuu 3. ja 5. iskulle ja aksenttiryhmät ovat muotoa $2+4$.

4) Sävelasteiden toteuttaminen. Sävelestä toiseen edetään liukumalla edelliseltä säveleltä. Joikaaja ei päästä ääntä katkeamaan sävelien välillä. Perussäveltä g väri- 
tetään vibratomaisesti käymällä kokosävelaskeleen ylemmällä sävelellä. E-sävelen kohdalla käytetään d-säveltä samalla tavoin. Alaspäisen hypyn yhteydessä c-sävelelle mennään h-sävelen kautta. Ilmiö on vastaavanlainen kuin edellisissä esimerkeissä tultaessa perussävelelle.

B-säkeen lopussa oleva as-sävel on hyvin korkealle intonoitu g-sävel. Tämä johtuu siitä, että joikaaja nostaa B-säkeen lopussa koko esityksen sävelkorkeutta.

Lyhyet kestot (LL) jaetaan tässä toisinnossa rytmisesti 16-osakuvioiksi kuten aiemmissakin toisinnoissa. Pitkät kestot $(\mathrm{P})$ puolestaan jaetaan kahteen, kolmeen tai neljään osaan. (ks. esim. 6b).

Esimerkki $6 b$. Sävelikön asteiden toteuttaminen.

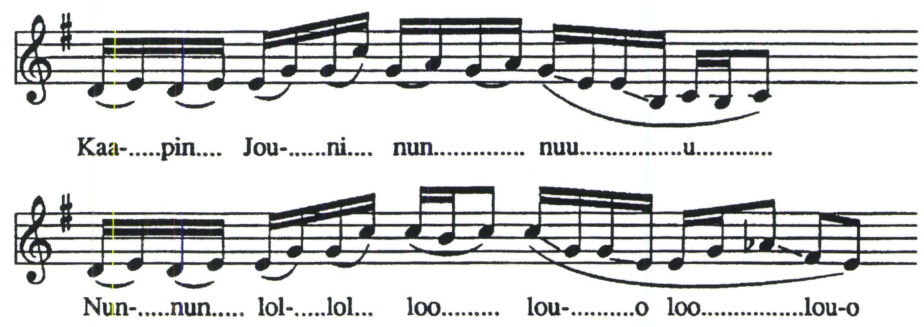

5) Muoto. Antti Proksin esittämä toisinto on kestoltaan pisin käsiteltävistä toisinnoista. Se sisältää 221 säettä, joista kolme on A-säettä, kaksi supistettua A-säettä ja 16 B-säettä. 
Kaavio $6 b$. Joiun melodiasäkeet. Säkeet Iskut

1. (A) B $2+6$

2. $\quad$ A $B \quad 4+6$

3. $\mathrm{A}$ B $4+6$

4. A B $4+6$

5. $\quad$ B 6

6. $\quad$ B 6

7. $\quad$ B $\quad 6$

\begin{tabular}{|c|c|c|}
\hline 8. & (A) & B \\
\hline 9. & & B \\
\hline 10. & & B \\
\hline 11. & & B \\
\hline 12. & & B \\
\hline 13. & & B \\
\hline 14. & & B \\
\hline 15. & & B \\
\hline 16. & & B \\
\hline
\end{tabular}

6) Hengitys. Esityksen kokonaiskesto on 1 min. $5 \mathrm{~s}$. Joiun aikana joikaaja hengittää vain kerran 34 s. kohdalla.

Amplitudikuvaaja 4. A-K 575/1

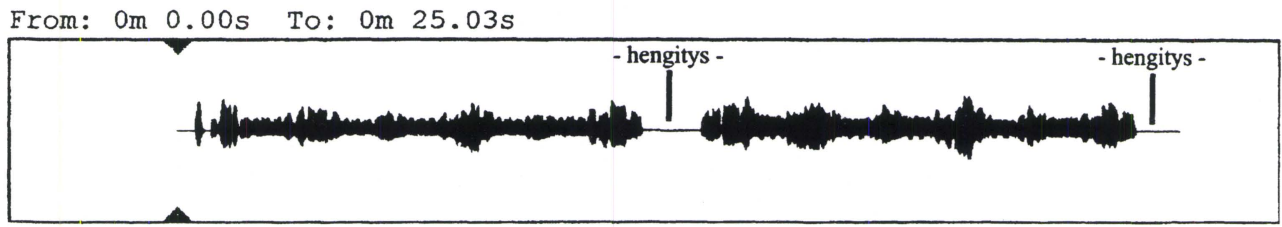




\section{Kaapin-Jounin joiulle ominaiset variointi- ja äänenkäyttötekniikat}

\subsection{Kaapin-Jounin joiun motiivi ja sen varioiminen}

Pintapuolisesti toisistaan paljonkin poikkeavat Kaapin-Jounin joiun toisinnot sisältävät saman melodisen ja metrisen aineiston. Variaatiota on paljon myös siksi, ettei ole olemassa mitään alkuperäistä versiota, joista muut toisinnot olisivat muuntuneet vaan jokainen joikaaja varioi suhteessa sekä omiin aiempiin että muiden esityksiin. Joiun esittäjällä on siis mielessään ennalta tuttu joiun kohteen perusmotiivi, josta hän lähtee toteuttamaan esitystä.

Kaapin-Jounin joiku koostuu kahdesta motiivista. A-motiivi koostuu ylös- ja alaspäisestä kvarttihypystä (g1 - c2 - g1 ). Tähän motiiviin liittyy useissa toisinnoissa myös kohteen sanallinen määrittäminen. B-motiivi muistuttaa edellistä, mutta melodian ylöspäinen liike etenee korkeammalle. Analysoimissani toisinnoissa noustaan suoraan kvinttiin (g1 - d2 - g1 ), välisävelen kautta sekstiin (g1 - a1 - e2 - g1 ) tai jopa septimiin (g1 - c2 - f2/f\#2 - g1 ) (ks. esim. 7).

Kaapin-Jounin joiun kahdesta säkeestä B-säe on A-säettä rytmisesti kiinteämpi. Säe A sen sijaan sallii vapaamman tulkinnan. Ehkä pidemmät sävelet antavat enemmän tilaa varioinnille kun taas non-no-tavuilla joikaaminen luo rytmisesti tiheämmän kudoksen.

Kaapin-Jounin joiun toisinnoista voidaan havaita erilaisia variointitekniikoita. Esimerkiksi melodiakaarta voidaan laajentaa lisäämällä iskuja B-säkeeseen. Tämä näkyy esimerkiksi siinä, että neljässä toisinnossa (L632b, A-K 1, A-K 2, A-K 3) Bsäe on yhden iskun pidempi kuin A-säe ja yhdessä toisinnossa (A-K 4) kaksi iskua pidempi:

(L632a: 4(2+2)+2)

(L632b: 4+5)

(A-K 1: 3+4)

S. $\quad$.

(A-K 2: 3+4)

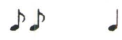

(A-K 3: 4+5)

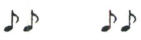

(A-K 4: 4+6)

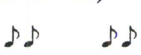


A-K 3:ssa kvarttihyppy on täytetty asteittaisella liikkeellä. Säveliä on siis lisätty melodian keskelle.

A-K 4 on erityisen kiinnostava sillä sen melodiassa on käytetty useampaa variaatiotekniikkaa yhtä aikaa. A-säkeen motiivin (g-c-g) alkuun on lisätty kaksi matalampala säveltä (e). B-säkeen loppuun on puolestaan lisätty kaksi ylimääräistä iskua. Melodiassa käytetään korkeiden sävelasteiden sijaan samoja säveliä oktaavia matalampaa.

Tekstin tavut ovat lähes aina samanlaiset samoissa metrin kohdissa. Tämä ei merkitse sitä, että teksti olisi välttämättä samalla kohdalla melodiassa. Esimerkiksi sanat Kaapin-Jouni ovat L632b.ssä a-säkeessä, L632a:ssa kolme ensimmäistä tavua ovat A-säkeessä ja neljäs tavu B-säkeessä. A-K 4:ssä nimi on kokonaan B-säkeessä.

Esimerkki 7. Kaapin-Jounin joiun toisintojen vertailu.

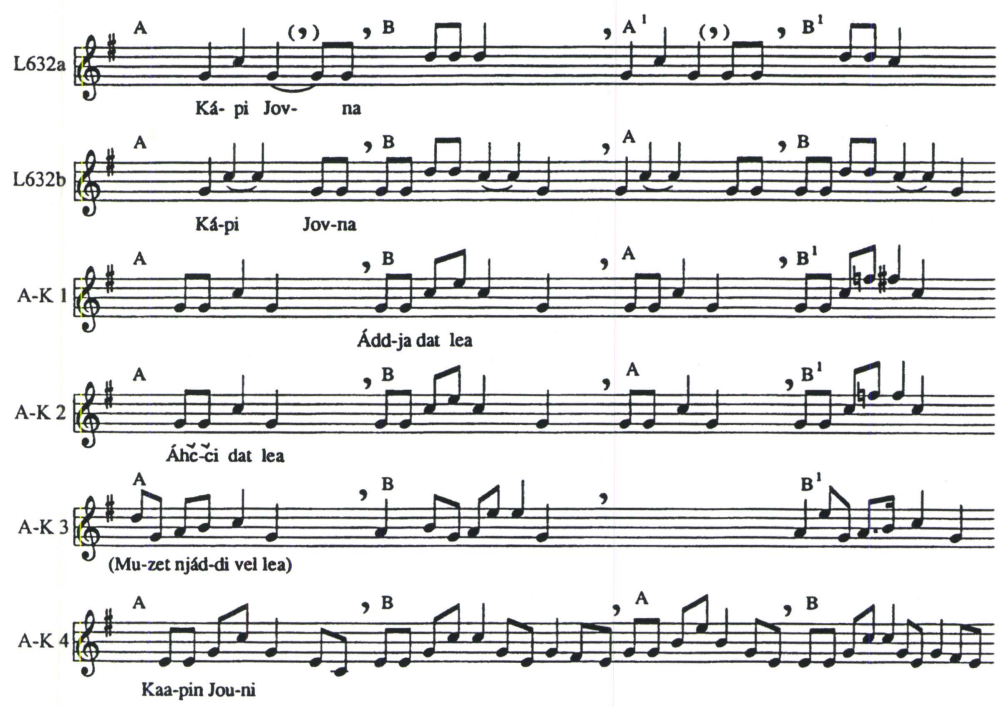

\subsection{Kaapin-Jounin joiun toisintojen säveliköt}

Kaapin-Jounin joiun toisintojen melodioista voidaan muodostaa sävelikkö, jonka perussävelenä on g, toisena sävelenä on c ja kolmantena d tai e. Kolmannessa ja neljännessä toisinnossa kolmas sävel intonoidaan vieläkin korkeammalle f-säveleen tai lähes f\#-säveleen saakka.

Kyseisessä joiussa käytetään siis kolmea sävelastetta: 1) matala perussävel (g); 2) korkea sävelaste (c) ja 3) korkein aste, joka on vielä edellistäkin korkeampi sävel, jonka sävelkorkeus voi vaihdella tilanteen ja joikaajan innostuksen mukaan d- 
sävelestä hyvin korkealle intonoituun f-säveleen. Joikaajan esityksen intensiteetin voimistuminen vaikuttaa esimerkiksi siten, että joikujen säveltaso nousee lähes aina esityksen aikana. Jos lähestytään joikaajan luonnollisen äänialan rajaa niin esimerkiksi korkeiden intervallihyppyjen sävelsuhteet saattavat muuttua. Karasjokelaisen joikaajan Mathis Hættan mukaan on myös tavallista, että joikaajan tunteiden vahvistuessa joiun aikana pyritään joikaamaan aina vain korkeampiin hyppyihin. Näin intervallit laajenevat. Hættan ajatus tuntuu sopivan varsinkin Kautokeinon, Karasjoen ja Enontekiön joikutyyleihin, joissa suositaan laajoja intervallihyppyjä. (Mathis Hættan haastattelu 1996.)

Joiun perusmotiivin ja perussävelen määrittelyssä kohteen nimen tunteminen ja tähän liittyvän motiivin huomioon ottaminen on ensisijaisen tärkeääas. Esimerkiksi kuudennessa Kaapin-Jounin joiun toisinnon (A-K 4) tulkinnassa voitaisiin päätyä varsin erilaisiin tuloksiin jos Kaapin-Jounin joiun motiiville ei olisi muita vertailukohtia. Matala c-sävel olisi helppo tulkita perussäveleksi koska perusmuotoinen kolmisointu korostuu niin voimakkaana. Kyse on kuitenkin joiun melodian varioinnista. Kaapin-Jounin motiivi löytyy myös tästä toisinnosta intervallisuhteiltaan muuttumattomana.

Mielenkiintoinen on myös viides toisinto (A-K 3). Oikeastaan vain tässä toisinnossa joiun sävelikössä on edellisistä toisinnoista poikkeavia säveliä, joilla on merkitystä melodian luonteen kannalta. Erityisesti B-säkeen aloittava a-sävel tuo melodiaan uuden olennaisen, perussäveltä kokosävelaskeleen yläpuolella olevan sävelasteen. On kuitenkin huomioitava, että toisinnot A-K 3 ja A-K 4 ovat Enontekiöläisten joikaajien sepittämiä kun taas muuta toisinnot ovat peräisin Inarin porosaamelaisilta. Eroihin vaikuttavat luonnollisesti alueelliset tyylierot. (ks. esim. 7b).

Esimerkki 8. Kaapin-Jounin joiun toisintojen sävelikköjen vertailu.

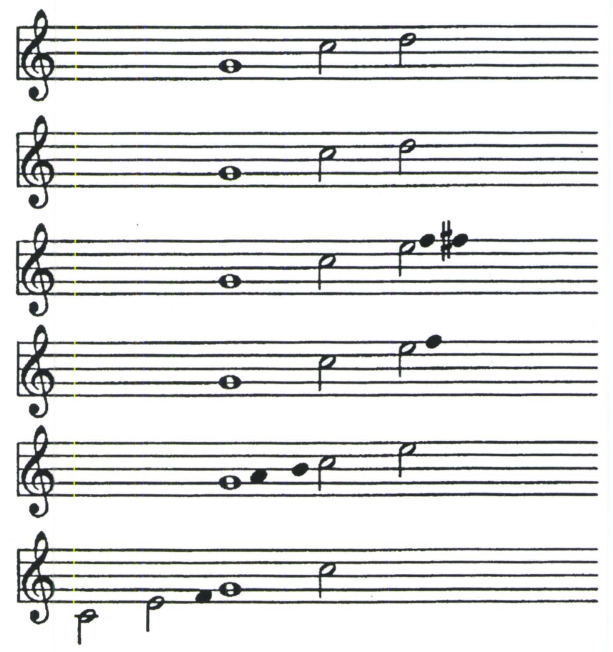




\subsection{Tekstin metrin ja sävelkorkeuksien suhde}

Toisintojen samankaltaisuutta kuvaa myös seuraava kaavio 7, jonka avulla vertailen tekstin metrin ja melodian sävelkorkeuksien yhteyttä. Koska tekstin metrin suhteen pitkät (P) ja lyhyet kestot (LL) osuvat vastaaviin asemiin, tekstin metrisen pohjakaavan voi esittää yhdellä rivillä. Olen jakanut melodian sävelet korkeisiin ja mataliin säveliin, joista matala on lähes aina perussävel (g). Merkki m tarkoittaa matalaa säveltä (g) ja merkki k tarkoittaa korkeaa säveltä (c, d)

Sävelkorkeuksien vertailu osoittaa, että melodian kokonaishahmo on kaikissa toisinnoissa sama. Korkeat ja matalat sävelet ovat metrin kannalta aina samoissa paikoissa. Tekstin metri on myös sama erityisesti B-säkeessä. Eri joikaajat aloittavat vain eri kohdista ja luovat näin persoonallista variaatiota joikuun.

Kaavio 7. Tekstin metrin ja melodian sävelkorkeuksien vertailu.

\begin{tabular}{llllllllll} 
Toisinto & A-säe & \multicolumn{9}{c}{ B-säe } \\
L632a & Pm & Pk & Pm & LLm & LLk & Pk & (P)m & \\
L632b & Pm & Pk & LLm & LLm & LLk & Pk & Pm & \\
A-K1 & LLm & Pk & Pm & LLm & LLk & Pk & Pm & \\
A-K2 & LLm & Pk & Pm & LLm & LLk & Pk & Pm & \\
A-K3 & & & Pm & LL & LL & Pk & Pm & & \\
A-K4 & & & & LLm & LLk & Pk & LLm & Pk & LLm
\end{tabular}

\subsection{Sävelasteiden toteuttaminen}

Länsimaisen taidemusiikin traditiosta lähtöisin olevien käsitteiden käyttäminen kansanomaisessa musiikissa kuten saamelaisessa joiussa on kyseenalaista. Erityisesti nuotinkirjoituskäytäntöihin liittyviä käsitteitä olisi syytä välttää joikujen analyysissa. Esimerkiksi korusävel on yksi tällainen käsite, jolle ei varsinaisesti löydy vastinetta suullisesta joikutraditiosta. Olenkin päätynyt sävelasteiden toteuttamisen käsitteeseen, jolla tarkoitan sitä, miten joikaajat tuovat melodiassa esille jonkun sävelasteen. Kaapin-Jounin joiun toisinnoista löytyi seuraavia tapoja:

1) Sävelasteen vahvistaminen ala- tai yläpuolisella johtosävelellä. Perussävelen kohdalla ilmeni kummankin perättäistä käyttöä. 2) Sävelasteen sävelkorkeuden nostaminen. Tämä koskee erityisesti laajoja intervallihyppyjä. Kvinttihypyn sijaan saatetaan päätyä ylinousevaan kvinttiin tai jopa sekstiin. 3) Liukuminen sävelestä toiseen vähentää sävelasteiden kestoa ja näin myös niiden hallitsevuutta melodiassa. 4) Joiulle tyypillinen säveltason nousu aiheuttaa myös muutoksia sävelasteissa, varsin- 
kin jos tullaan joikaajan äänialan rajalle. Uula Aikion joikuesitykset olivat kestoltaan sen verran lyhyitä, ettei säveltaso ehtinyt nousta kuin noin puolisävelaskeleen verran. Antti Proksin esityksessä säveltaso nousi kvartilla.

Joikumelodioissa esiintyvät sävelasteet voidaankin jakaa kahteen ryhmään: 1) On olemassa sävelasteita, joilla pysytään kauemman aikaa ja jotka muodostavat melodian perusrungon sekä 2) sävelasteita, joilla haetaan, autetaan ja varmistetaan edellisiä. Näillä on myös rytminen merkitys, sillä niillä pidetään pulssia pitkien sävelien aikana. Tämä tekniikka on läheinen vibraton käytön kanssa, mutta ainakin KaapinJounin joiun toisinnossa samaa rytmistä elementtiä käytettiin säännöllisesti aina tietyillä kohdilla melodiassa. Myös pikkusanoilla nonnotteluun liittyy liukumisesta aiheutuva rytminen vaikutus. Yksi non-no luo neljän 16-osan rytmiyksikön, jossa ensimmäistä ja kolmatta painotetaan ja näin saadaan aikaan hyvin liikkuva rytmi.

Periaatteessa kuitenkin nämä molemmat ryhmät tulisi huomioida analyysin tuloksina saaduissa säveliköissä. Koska joiussa on vain oma ääni, sen hallinta on erittäin tarkkaa ja sitä kuunnellaan. Juuri nämä melodian hienovaraisimmat piirteet toteuttavat joiun kommunikatiivista puolta.

\subsection{Joiulle tyypillinen hengitysteniikka}

Joiulle tyypillisen hengitystekniikan vaikutukset näkyvät kolmessa joiun musiikillisessa piirteessä. Ensinnäkin tavallisin tapa siirtyä sävelestä toiseen on liu'uttaa ääni, vaikkakin liukumisen nopeus vaihteleekin. Joissain kohdin voidaan liukua hitaasti liukumista korostaen. Toisin paikoin liu'utaan puolestaan hyvin nopeasti. Olennaista kuitenkin on se, ettei sävelestä voi siirtyä toiseen ilman liukua jos ääntä ei katkaise välillä.

Seuraavassa nuottiesimerkissä (9a) on Kaapin-Jounin joiun (A-K/1) ensimmäinen säepari. Äänen katkeaminen soinnittomien konsonanttien $(\mathrm{p}(\mathrm{b}), \mathrm{k}(\mathrm{g}), \mathrm{t}(\mathrm{d}))$ edellä, kahden konsonantin välissä $(\mathrm{t} / \mathrm{s}, \mathrm{s} / \mathrm{h}, \mathrm{d} / \mathrm{j})$ ja kaksoiskonsonanttien ( $\mathrm{g} / \mathrm{g}, \mathrm{v} / \mathrm{v})$ välissä on merkitty nuottiin merkillä $\mathrm{V}$ ja tekstiin merkillä //.

Esimerkki 9a. Äänen katkeaminen Kaapin-Jounin joiun (A-K/1) ensimmäisen säeparin aikana.

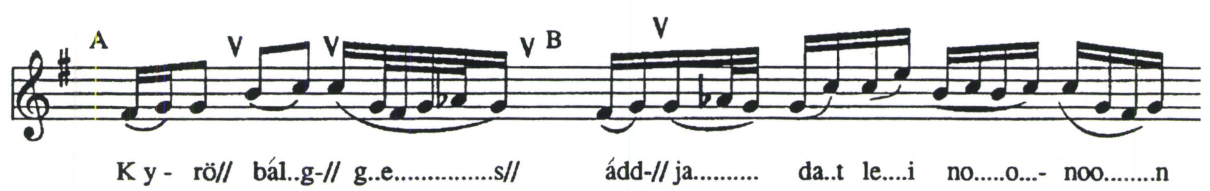


Toiseksi näyttää siltä, että syy tavujen valintaan liittyy juuri äänen katkeamisen välttämiseen. Eniten käytetyt tavut (non-no, nun-nun, lol-lol, lul-lul) sisältävät vain soinnillisia konsonantteja ja ne voidaan joikata ääntä katkaisematta. Näin voidaan jatkaa joikaamista ilman äänen katkeamista mahdollisimman pitkään. Äänen katkeamisessa voidaan havaita myös periaatteellinen ero joiun tekstin ja pikkusanoilla nonnottelun välillä.

Kolmas hengitystekniikkaan liittyvä piirre on se, että joikaaja joikaa niin kauan kuin ilmaa riittää ja hengittää vasta ilman loppuessa. Jos joikaajia on useampia, kukin hengittää vuorotellen siten ettei itse joiku pääse katkeamaan. ${ }^{26}$ Tässä yhteydessä käsitellyistä joikuesityksissä harvimmin hengittää Antti Proksi. Minuutin kestävän joikuesityksen aikaan hän hengitti vain kerran 34 s. kohdalla. Kaapin-Jounin joiun neljässä esityksessä hengitystaukojen paikat ovat seuraavan kaavion 8 mukaisia.

Kaavio 8. Hengitystaukojen paikat neljässä Kaapin-Jounin joiun esityksessä.

\begin{tabular}{llll} 
Joiku & \multicolumn{3}{l}{ Hengitykset } \\
& 1. & 2. & \multicolumn{2}{l}{3.} \\
A-K/1 & $21 \mathrm{~s}$. & $34 \mathrm{~s}$. & - \\
A-K/2 & $13 \mathrm{~s}$. & $25 \mathrm{~s}$. & - \\
A-K/3 & $14 \mathrm{~s}$. & $30 \mathrm{~s}$. & $39 \mathrm{~s}$. \\
A-K/4 & $34 \mathrm{~s}$. & $1 \mathrm{~min}$. & $5 \mathrm{~s}$.
\end{tabular}

Hengitystekniikka muodostaa merkittävän eron joiun ja länsimaisen laulun välillä. Seuraavassa esimerkissä on ensimmäinen säepari laulusta Heilani lähti Amerikkahan. Fraasien välillä on hengitystauko.

Esimerkki 9b. "Heilani lähti Amerikkahan" Anna-Kaisa Liedeksen esittämänä. (OMCD 44, 7)

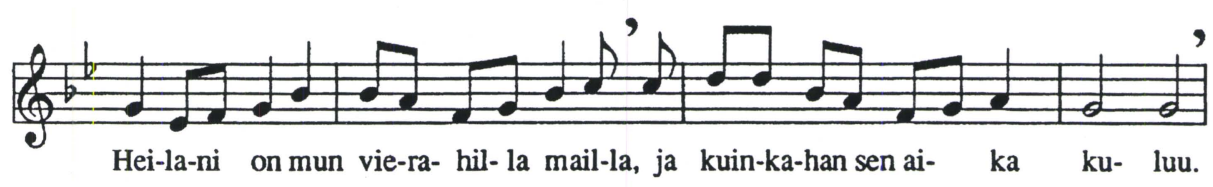

Amplitudikuvaajan avulla tarkasteltuna säkeiden ja puolisäkeiden välisten hengityspaikkojen tiheys länsimaisessa laulussa käy ilmi hyvin selkeästi. Olen merkinnyt pystyviivalla laulajan hengitykset ensimmäisen säkeistön aikana. Tästä 48 s. pituista säkeistöä voidaan verrata ajallisesti aiemmin käsiteltyihin joikuesityksiin. 
Hengitystauot ajoittuvat seuraavasti: 6 s., 12 s., 19 s., 24 s., 31 s., 43 s. ja 48 s. Käsitellyissä joikuesityksissä hengitettiin vain kerran vastaavan pituisena aikana.

Amplitudikuvaaja 5. "Heilani lähti Amerikkahan" (OMCD 44, 7) Hengitysmerkit on merkitty vain ensimmäisen säkeistön kohdalle.

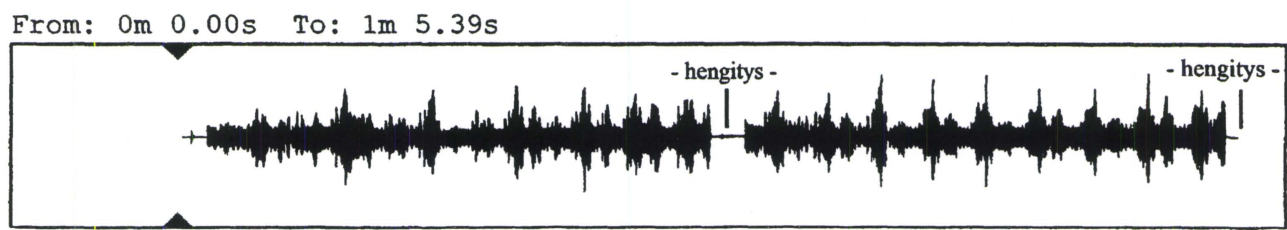

\section{Päätelmä}

Saamelaista joikua on käsitelty tutkimuskirjallisuudessa useimmiten laajoina aineistoina, joista on etsitty asteikkoja saamelaisen säveljärjestelmän määrittämiseksi. Tässä artikkelissa olen kiinnittänyt huomion siihen, millaisille aineksille joikaaja on rakentanut jo aiemmin tuntemansa melodian esityksen.

Käsittelyt neljä joikaajaa tuottivat hyvinkin erilaisia toisintoja Kaapin-Jounin joiusta. Ensikuulemalta oli jopa hankala tunnistaa osaa toisinnoista samaksi joiuiksi. Tarkempi analyysi kuitenkin osoitti, että analysoidut toisinnot perustuivat samaan melodiseen ja metriseen perusideaan Kaapin-Jounin joiun motiivista. Tähän motiiviin liittyy olennaisesti joiun kohteen eli Kaapin-Jounin nimi. Jos nimeä ei mainita, se on korvattu rytmisesti yhteensopivilla sanoilla.

Joikaajat varioivat Kaapin-Jounin joiun melodiaa seuraavanlaisin tavoin:

1) melodian kaaren laajentaminen tai supistaminen eli iskujen lisääminen tai vähentäminen

2) laajojen intervallien sävelsuhteiden muuttaminen

3) melodian hyppyjen täyttäminen välisävelillä

4) sävelten siirtäminen oktaavilla alas

Tämän aineiston perusteella voidaan sanoa, että melodian variointikeinot tuntuvat hyvin yleismaailmallisilta. Joikaaja leikittelee sävelillä ja rytmillä luodessaan uusia variaatioita tutusta motiivista. Lisäksi analyysissä huomio kiinnittyi hyvin tarkkaan ja säädeltyyn tapaan toteuttaa sävelasteet. Sävelasteiden korkeutta tuetaan apusävelillä. Käytössä ovat niin alapuolinen kuin yläpuolinen puolisävelaskel suhteessa 
pääsäveleen. Apusävelillä on myös rytmiä tuottava vaikutus. Sävelistä toisiin edetään liukuen. Tämä tekniikka selittyy joiulle tyypillisellä hengitystekniikalla. Yhdellä hengityksellä joikataan niin kauan kuin ilmaa riittää eikä ääntä päästetä katkeamaan hengitystaukojen välillä.

Kaikki nämä asiat toteuttavat yhdessä sekä joiun musiikillista ihannetta että kommunikatiivista puolta. Joiun tärkein tehtävä on pystyä kuvaamaan kohteensa täydellisesti. Jos emme tunne kohdetta ja joiun tapaa kuvata kohteensa, joiku jää avautumatta. Mutta kyllä kokenutkin joikaaja voi joikata henkilöitä, joita hän ei tunne kovin hyvin. Antti Proksi sanoi Kaapin-Jounin joikauksen jälkeen ettei "KaapinJounia tunnettu niin kovin hyvin Enontekiöllä”. Mutta joikasipa Antti hänet kuitenkin.

\section{Lähteet ja kirjallisuus}

\section{Arkistoaineisto:}

Inarin kirkon arkisto (IKA) Inarin kirkonkirjat 1901-1910.

Tampereen yliopiston kansanperinteen laitoksen arkisto (TaY/KPL) A-K 539; A-K 541, A-K 546, 575, Ala-Könnin joikukokoelma.

Oulun maakunta-arkisto (OMA) Inarin kirkonkirjat.

Haastattelut:

Keskustelu Jouni Maggan kanssa 12.5.2000.

Mathis Hættan haastattelu 1996. Hetta. Haastattelijana Marko Jouste.

\section{Äänitteet:}

Valkeapää, Nils-Aslak,"Vál'gon guoi'ka", Finlandia CD 3984-221112-2, 16.

Liedes, Anna-Kaisa, "Heilani lähti Amerikkahan", Kuuttaren korut, OMCD 44, 7

\section{Kirjallisuus:}

Akujärvi, Anja 1996. Morottajan suku. Tornio.

Jouste, Marko 1998. Change and Metrics in Guhtura-Niilla's yoik. Etnomusikologian vuosikirja 10, toim. Jukka Louhivuori. Helsinki: Suomen etnomusikologinen seura, 44-64.

Järvinen, Minna Riikka 1999. Maailma äänessä. Tutkimus pohjoissaamelaisesta joikuperinteestä. Suomalaisen kirjallisuuden seuran toimituksia 762. Helsinki: SKS.

Kantola, Tuula 1984. Talvadaksen joikuperinne. Etnomusikologinen perustutkimus tenonsaamelaisten musiikista. Folkloristiikan tutkimuksia 2. Turku: Turun yliopisto.

Laitinen, Heikki 1981. Saamelaisten musiikki. Kansanmusiikki, toim. Anneli Asplund \& Matti Hako. Helsinki: SKS, 179-189.

Launis, Armas 1908. Lappische Juoigos-Melodien. Suomalais-ugrilaisen seuran toimituksia XXVI. Helsingfors: Société Finno-Ougrienne.

Launis, Armas 1922. Kaipaukseni maa. Lapinkävijän matkamuistoja. Jyväskylä: K. J. Gummerus Osakeyhtiö.

Launis, Armas 1986. Kertomukset kansansävelmäin keräysmatkoista Norjan ja Suomen Lapissa kesällä v. 1904 ja 1905. Kansanmusiikki 2/1986, 14-24.

Nahkiaisoja, Tarja 1998. Inarin asutushistorian piirteitä 1800-luvulla. Kirjoituksia Inarin historiasta, toim. Veli-Pekka Lehtola. Inari: Puntsi, 61-68.

Paulaharju, Samuli 1927. Taka-Lappia. Helsinki: Kustannusosakeyhtiö Kirja. 
Saastamoinen, Ilpo 1998. Laulu-puu-rumpu. Saamelaismusiikin alkulähteillä. Lisensiaattityö (painamaton). Jyväskylän yliopiston musiikkitieteen laitos.

Sammallahti, Pekka 1989. Sámi-suoma sátnegirji. Saamelais-suomalainen sanakirja. Ohcejohka: Jorgaleaddji Oy.

Tikkanen, Heikki 1964. Suomen ja Norjan Lapin rajaneuvottelut 1829-52. Neuvottelut Suomen ja Norjan Lapin raja-alueiden vastavuoroisista käyttöoikeuksista v. 1829-52. Suomen historian laudaturtutkielma. Jyväskylän yliopisto.

\section{Viitteet}

${ }^{1}$ Käytän nimitystä porosaamelainen tässä yhteydessä tarkoittaen Inarin poronhoitajasukuja erotukseksi muusta Inarin saamelaisväestöstä. Yleisesti käytetyin nimitys on tunturisaamelainen (saam. badjesápmelaš) tai pohjoissaamelainen (saam. davvisápmelaš), mutta nämä muodostavat tämän työn kannalta liian laajan väestönosan. Lisäksi Saastamoisen $(1998,91)$ mukaan 1900-luvun alkupuoliskolla, johon tutkimukseni liittyy, pidettiin elinkeinojakoa miltei tärkeimpänä perusteena saamelaisten kielelliseen aluejakoon.

${ }^{2}$ Entistä laajempi suomalaisasutus levisi Lappiin 1800-luvun alkupuoliskolla, ja sen seurauksena Inarin alueella oli liian paljon peuran ja majavan pyytäjiä eläinkantoihin nähden. Samaan aikaan myös Utsjoen, Kautokeinon ja Karasjoen poropaimentolaisten porotokat kasvoivat ja heidän talvilaidunalueensa laajentuivat aina Inariin ja Pohjois-Sodankylään asti. Vähentynyt peurakanta sekaantui myös porotokkiin ja Inarin metsäsaamelaisten vanha elintapa oli häviämässä. Tultaessa 1840-luvulle inarilaiset olivat kuitenkin jo pitkälti sopeutuneet uuteen tilanteeseen ja keksineet uusia selviytymistapoja. Toiset hankkivat lisätuloja Ruijan fiskuusta ja toiset siirtyivät karjatalouteen, toiset opettelivat laajamuotoisen porotalouden. (ks. esim. Tikkanen 1964, Nahkiaisoja 1998.)

${ }^{3}$ Annas-Kaapi eli Annan Kaapi oli saanut lisänimensä saamelaiseen tapaan vahvempana persoonana pidetyn vanhemman, tällä kertaa äitinsä Annan mukaan (Paulaharju 1927, 120-121). Hän perusti kruununtorpan Appijoensuuhun.

${ }^{4}$ Margareeta Aslakintr. Aikio (os. Jomppanen) (s. 1884), Uula Aikio Kaapin Jounin Uula tai PikkuUula (s. 1915) Ks. TAY/KPL, A-K 539; A-K 541, A-K 546; IKA mf. Aa10 Pad7 163.

${ }^{5}$ Tekstin ja metrin analyysissä käytän aiemmin (Jouste 1998, 44-63) esittelemääni metodia.

${ }^{6}$ Alueellisia tyylialueita ovat määritelleet mm. Kantola (1984, 35-41) ja Saastamoinen (1998, 91-109).

7 Aslak Jomppanen kuului myös Launiksen joikumestareihin. Kokoelmassa on 61 häneltä tallennettua joikua (Launis 1908, 183-184).

${ }^{8}$ Aslak Aslakinp. Jomppanen (s. 1882) (Akujärvi 1996, 46).

9 Launikselta otetuissa esimerkeissä noudatan hänen käyttämäänsä saamen kielen kirjoitustapaa. Hänellä ei ollut vuoden 1905 matkallaan tulkkia, mutta Inarin kirkkoherra L. Itkonen auttoi Launista sävelmien sanojen oikeinkirjoituksessa (Launis 1986, 15).

${ }^{10}$ Launiksen $(1986,16)$ mukaan "[...]joikaus ei ole laajempimuotoinen, kuten kansanlaulut yleensä, se on vaain saman lyhyen sävelen yksitoikkoista kertaamista."

${ }^{11}$ Lauris ei kerro informanttinsa sukunimeä. Todennäköisesti kyseessä on inarilainen kalastaja Matti Walborginpoika Musta (s. 1873) (OMA mf. 536), joka toimi myöhemmin myöskin Samuli Paulaharjun informanttina (ks. Paulaharju 1927, 322).

${ }^{12}$ Detaljina voidaan mainita, että jos säkeen rytmin jakaa keskeltä kahtia, saadaan kummastakin puoliskosta täysin symmetrinen rytmikaava.

13 TaY/KPL A-K 541.

${ }^{14}$ Keskustelu Jouni Maggan kanssa 12.5.2000.

${ }^{15}$ Sana áddjá tarkoittaa ukkia, äijää, ikäihmistä. Sanaa käytetään myös puhuttaessa omasta isästä, jos tämä on saavuttanut korkean, kunnioitettavan iän. Saamelaisessa perheenjäsenten nimityksissä onkin varsin tavallista käyttää henkilön korkeinta sukuun liittyvää statusta. Tässä tapauksessa se on áddjá. Keskustelu Jouni Maggan kanssa 12.5.2000.

${ }^{16}$ Käytän teksteissä ymmärrettävyyden vuoksi pohjoissaamen nykyistä ortografiaa - vaikka se ei ollutkaan käytössä vielä 1960-luvulla - ja myös siksi että erot ovat käsittelemissäni teksteissä sangen 
vähäisiä. Merkittävimmät erot kirjoitetun kielen ja ääntämyksen välillä näkyvät lähinnä eräiden soinnillisten konsonanttien soinnittomina ääntymisenä (esim. $\mathrm{b} \rightarrow \mathrm{p}, \mathrm{g} \rightarrow \mathrm{k}, \mathrm{d} \rightarrow \mathrm{t}$ ); vokaaleissa eroa on puolestaan pitkän á:n ja lyhyen a:n välillä (á $\rightarrow$ aa tai ää). Merkittävin vaikutus esim. joikutekstien rytmiikkaan tulee kuitenkin švaa-vokaalien ja h:n lisäämisestä sanoihin, joissa ne eivät näy kirjoitusasussa. Koska näitä tapauksia ei tunnista kuin saamen kieltä taitava, olen merkinnyt ne tekstiin sulkuihin.

${ }^{17}$ Tutkimuskirjallisuus on eri asia, eikä sillä ole ollut merkitystä käytännön joikuperinteeseen ainakaan analyysin kohteena olevien joikujen ajankohtana.

${ }^{18}$ Sävelikön asteiden toteuttamista kuvaavissa esimerkeissä olen erottanut nämä tapaukset merkillä (3).

19 TaY/KPL A-K 541.

${ }^{20}$ TaY/KPL A-K 541. Heikin Niila eli Niila Heikinp. Magga.

${ }^{21}$ Muzet (suom. musikki, muzikki) tarkoittaa mustaa, tummakarvaista poroa. Njáide (suom. naiti) tarkoittaa ylvästä, takakenosarvista poroa.

22 Yleisemmin maaselkä eli maan selkä tarkoittaa korkeaa ympäristöstään erottuvaa paikkaa, vaaraa. Myös yksittäisiä paikkoja on nimetty tällä nimellä. Koparat ovat poron kynnet ja porotokan juostessa kuuluu eräänlaista humisevaa kopsetta.

${ }^{23}$ Sanassa muzet kuuluu saamenkielelle tyypillinen h-äänne ennen t:tä. Samoin sana dat ääntyy taht.

${ }^{24} \mathrm{TaY} / \mathrm{KPL}, \mathrm{A}-\mathrm{K} 575$.

${ }^{25}$ Laitinen ja Kantola ovat tulkinneet samantyyppisiä joikujen säveliköitä siten, että niiden alimpana sävelenä on kvintin alaoktaavi ja keskellä on perussävel (V-1-2 tai V-1-3). (Ks. Kantola 1984; Laitinen 1981.)

${ }^{26}$ Ks. esim. Johan N. P. Eiran, Elen-Anne Buljon ja Josef P. Buljon yhteisjoikaus Vál'gon guoi'ka (Finlandia CD 3984-221112-2, 16). 